\title{
Water balance components estimation under scenarios of land cover change in the Vea catchment, West Africa
}

\author{
*Isaac Larbi ${ }^{1}$, Emmanuel Obuobie ${ }^{2}$, Anne Verhoef ${ }^{3}$, Stefan Julich ${ }^{4}$, Karl- \\ Henz Feger ${ }^{4}$, Aymar Yaovi Bossa ${ }^{5}$ and David M. J. Macdonald ${ }^{6}$ \\ 1Climate Change and Water Resources, West African Science Service Centre on \\ Climate Change and Adapted Land Use (WASCAL), Universite d'Abomey Calavi, \\ Cotonou, Benin
}

2Water Research Institute, CSIR, Accra, Ghana;

3 Department of Geography and Environmental Science, University of Reading, Reading, UK

4 Institute of Soil Science and Site Ecology, Technische Universität Dresden, Dresden, Germany

5 National Water Institute, University of Abomey Calavi, Cotonou, Benin

6 British Geological Survey, Wallingford, Oxfordshire, UK

*Corresponding author: larbi.i@edu.wascal.org

\begin{abstract}
The need for a detailed investigation of the Vea catchment water balance components cannot be overemphasized due to its accelerated land cover dynamics and the associated impacts on the hydrological processes. This study assessed the possible consequences of land-use change scenarios (i.e. business as usual, BAU, and afforestation for the year 2025) compared to the 2016 baseline on the Vea catchment's water balance components using the Soil and Water Assessment Tool (SWAT) model. The data used include daily climate and discharge, soil and land use/land cover maps. The results indicate that the mean annual water yield may increase by $9.1 \%$ under the BAU scenario but decrease by $2.7 \%$ under the afforestation scenario; actual evapotranspiration would decrease under BAU but increase under afforestation; and groundwater recharge may increase under both scenarios but would be more pronounced under the afforestation scenario. These outcomes highlight the significance of land cover dynamics in water resource management and planning at the catchment.
\end{abstract}

Keywords water balance components; Vea catchment; SWAT modelling; land cover change scenarios 


\section{INTRODUCTION}

Although freshwater constitutes less than $3 \%$ of the world's water resources, it forms an important part of all terrestrial ecosystems. Concerns about the management of this limited resource in river basins have been on the increase due to changes in climatic conditions combined with anthropogenic influences (Jones et al. 2015, Zhang et al. 2008). Effective catchment management requires a thorough knowledge of the hydrological processes and their spatial distribution over the catchment (Wang et al. 2015). Land use/land cover (LULC) change is one of the main human induced activities which potentially impacts hydrology and water resources by affecting different hydrological processes and stores in the catchment (Bhaduri et al. 2000, Tang et al. 2005, Stonestrom et al. 2009). The changes in LULC have a direct and significant impact on the amount of evapotranspiration, surface runoff and groundwater recharge driven by infiltration during and after precipitation events (Doerr et al. 2000, Wei et al. 2013).

In the past decades, modelling of hydrological response to the changes in LULC has become increasingly important. The changes in LULC, such as the conversion of forest to agriculture and urban areas, have accelerated the rate of surface runoff and also affected other water balance components (Costa et al. 2003, Jat et al. 2009, Awotwi et al. 2014). A study conducted by Mwangi et al. (2016) on agroforestry impact on the hydrology of the Mara river basin, East Africa found a decrease in water yield (surface runoff, groundwater flow and lateral flow) due to the increase in tree cover. A similar study by Mango et al. (2010) investigated the hydrological response of the Mara River basin to land-use change and found a decrease in river baseflow and average streamflow due to the conversion of forest to agriculture and grassland. Using a semi-distributed hydrological modelling approach, Awotwi et al. (2014) estimated that the conversion of savanna (30.2\%) and grassland (56.2\%) to cropland caused a decrease in surface runoff and groundwater during the period from 1990 to 2006 in the White Volta basin (WVB) in West Africa. The above studies confirm that the water resources are under threat from the effects of LULC change.

In the past decades, several hydrological models have been developed to simulate the water balance of catchments, especially in data scarce regions. These catchment models are generally applied for water balance assessments (Ghoraba 2015, Vilaysane et al. 2015, Bansode and Patil, 2016, Yin et al. 2016) or climate/land-use change impact assessments (Zhang et al. 2008, Mohamed, 2010, Palazzoli et al. 2015). Among these models, the physically based semi-distributed Soil and Water Assessment Tool (SWAT) 
model is a well-established model for estimation of water balance components, as well as for the analysis of the impact of land management practices on water, sediment and agricultural chemical yields in large complex catchments (Arnold et al. 1993). The SWAT model is one of the most widely used hydrologic models and has been applied in the USA, China, Europe, South Asia and Africa (Abbaspour et al. 2009). Hydrological models face challenges in terms of data requirements, spatial heterogeneity of basin characteristics, and how to represent complex terrestrial systems by model equations. SWAT is capable of overcoming some of these challenges (Gassman et al. 2007). The model has been used for a wide range of applications such as those relating to hydrology, including hydrological climate change impact studies (Gassman et al. 2007). In West Africa, a number of studies (Schuol and Abbaspour, 2007, Obuobie 2008, Kasei 2010, Kankam-Yeboah et al. 2013, Bossa et al. 2014) evaluated the SWAT model favourably in the context of water balance simulation. For example, Obuobie (2008) applied the SWAT model in the WVB to simulate the water balance components and found a good agreement between simulated and observed annual discharge, surface runoff and baseflow with a coefficient of determination $\left(\mathrm{R}^{2}\right)$ and Nash-Sutcliffe model efficiency (NSE) both greater than 0.80. Other studies, such as Awotwi et al. (2015), also confirmed that the SWAT model was able to simulate reliably the hydrology of the WVB, hence the use of SWAT in our study.

Freshwater availability and distribution have been declining over time partly due to changes in LULC and population growth. Studies such as Braimoh and Vlek (2004), Forkuor (2014), and Batuuwie (2015) have all reported substantial changes in LULC over recent years within the Volta basin, where the Vea catchment is located. The study by Batuuwie (2015) indicated that a significant portion of natural vegetation cover in the WVB, has been lost over the years partly due to human activities. Similarly, a study by Larbi et al. (2019) indicated the conversion of forest/mixed vegetation to cropland as the dominant LULC from 1990 to 2016 in the Vea catchment. Their projection of LULC predicted continuous expansion of cropland at the expense of forest/mixed vegetation with an estimated decrease of non-agricultural vegetation of $4.5 \%$ between 2016 and 2025, under business as usual scenario (Larbi et al. 2019). This unfavorable situation of LULC change has heightened the need for afforestation and the protection of forest reserves in most river basins in Ghana such as the Vea catchment. There is however a trade-off between afforestation and surface water resources. For example, forest improves water quality and enhances infiltration but uses more water, causing higher 
evapotranspiration and lower runoff (Yira et al. 2017). Hence, there is an urgent need for catchment scale water balance information since the changes in LULC have been shown to alter the hydrological processes of many river basins (Stonestrom et al. 2009, Mwangi et al. 2016). In the study region, although Awotwi et al. (2014) undertook a broader scale study of LULC change impact on water resources on the entire White Volta basin, little is known at the local scale (e.g. for a sub-catchment such as the Vea). The previous largescale study of LULC change impacts on water balance have used coarse resolution data for land use, digital elevation model (DEM) and soil, which may ignore or over-simplify landscape characteristics that relate to the hydrology of the Vea catchment. Having a higher resolution DEM and LULC data provides better details for drainage, slope and related land-use types for small scale catchments. According to the study by Sivasena and Janga (2015), the accuracy of sub-catchments decreases with coarse resolution data, and this affects the generated runoff at the HRU level within each sub-catchment. There is also the issue of data scarcity and uneven distribution of climate stations in the catchment that hampers spatio-temporal studies of the various components of the water balance (Ibrahim et al. 2015). The issue of data scarcity is a challenge in Ghana, hence the need to rely on high-resolution satellite-based climate products for hydrological studies.

Moreover, in the Vea catchment there is a proposed initiative to increase the number of small dams or dugouts with the aim of ensuring all year-round crop production. This initiative as a result may increase cropland area in the future and also affect other land-use types, which would eventually alter the water balance of the catchment. Given the reviewed impacts of LULC change on hydrological processes in Ghana, the need for a detailed investigation of the Vea catchment water balance components cannot be overemphasized due to its accelerated land cover dynamics and its associated impacts on the hydrological processes. This study assessed the possible consequences of land-use change scenarios (i.e. business as usual and afforestation, for the year 2025) compared to the 2016 baseline, on the water balance components of the Vea catchment (i.e. actual evapotranspiration, surface runoff, water yield and groundwater recharge ) using the Soil and Water Assessment Tool (SWAT) model. The specific objectives of this study are to: (a) apply the SWAT model to simulate the water balance components of the data-scarce Vea catchment using both weather station and high-resolution (5-km) gridded precipitation data; and (b) estimate the impact of business-as-usual (BAU) and afforestation scenarios of land cover change on the water balance components. The BAU scenario deals with the projection of the LULC pattern based on expansion in cropland 
and grassland at the expense of forest/mixed vegetation, while the afforestation scenario deals with the by limiting cropland expansion into the forested areas and increasing natural vegetation (forest cover and grassland). The study provides information on the present water balance components of the catchment and the implication of different scenarios of LULC change on the future water resources which are relevant to decision makers for a sustainable management of the land and water resources of the Vea catchment.

\section{MATERIALS AND METHODS}

\subsection{Study area}

The Vea catchment, with an area of $306 \mathrm{~km}^{2}$, is one of the three focal experimental catchments of the West African Science Service Center on Climate Change and Adapted Land Use (WASCAL); it is located within the White Volta basin (Figure 1). The Vea catchment covers mainly the Bongo and Bolgatanga districts in the Upper East region of Ghana and lies between $10^{\circ} 30^{\prime}-11^{\circ} 08^{\prime} \mathrm{N}$ and $0^{\circ} 59^{\prime}-0^{\circ} 45^{\prime} \mathrm{W}$. The catchment lies mainly in Ghana, with a small northern portion located in the south-central part of Burkina Faso. The climate of the catchment is controlled by the movement of the Inter-Tropical Discontinuity (ITD) that dominates the climate of the entire West African region (Obuobie 2008). Located in a semi-arid agro-climatic zone, the catchment covers three agro-ecological zones: the Savanna and Guinea Savanna zones in Ghana, and north Sudanian Savanna zone in Burkina Faso (Forkuor 2014). It is characterized by a unimodal rainfall regime from April/May to October with a mean annual rainfall of $957 \mathrm{~mm}$, which normally peaks in August, and a very high potential evapotranspiration with a mean annual value ranging from 1650 to $1950 \mathrm{~mm}$ (Limantol et al. 2016, Larbi et al. 2018). It is characterized by fairly low relief with elevation ranging between 89 and $317 \mathrm{~m}$ (Figure 1) and mainly dominated by cropland followed by grassland interspersed with shrubs and trees, and woodland (closed/open) (Figure 2) (see also Section 2.2). The dominant soil type in the Vea catchment is lixisols (90\%) while vertisols $(8 \%)$ and cambisols $(2 \%)$ occur in relatively smaller proportions (Figure 2 ). The catchment also contains a considerable number of wetlands and valleys, as well as the Vea Dam and many small dams (used for irrigation and animal watering) and wells/pumps, resulting in a complex hydro-ecological system. Agriculture (rain-fed and irrigated), which includes the cultivation of annual crops such as: beans, rice, sorghum, millet, and groundnuts is one of the main sources of income for many of the rural people in the catchment. The 
construction of the Vea irrigation project in the 1980s for irrigation farming and provision of potable water to the surrounding communities has led to changes in LULC in the catchment (Adongo et al. 2014).

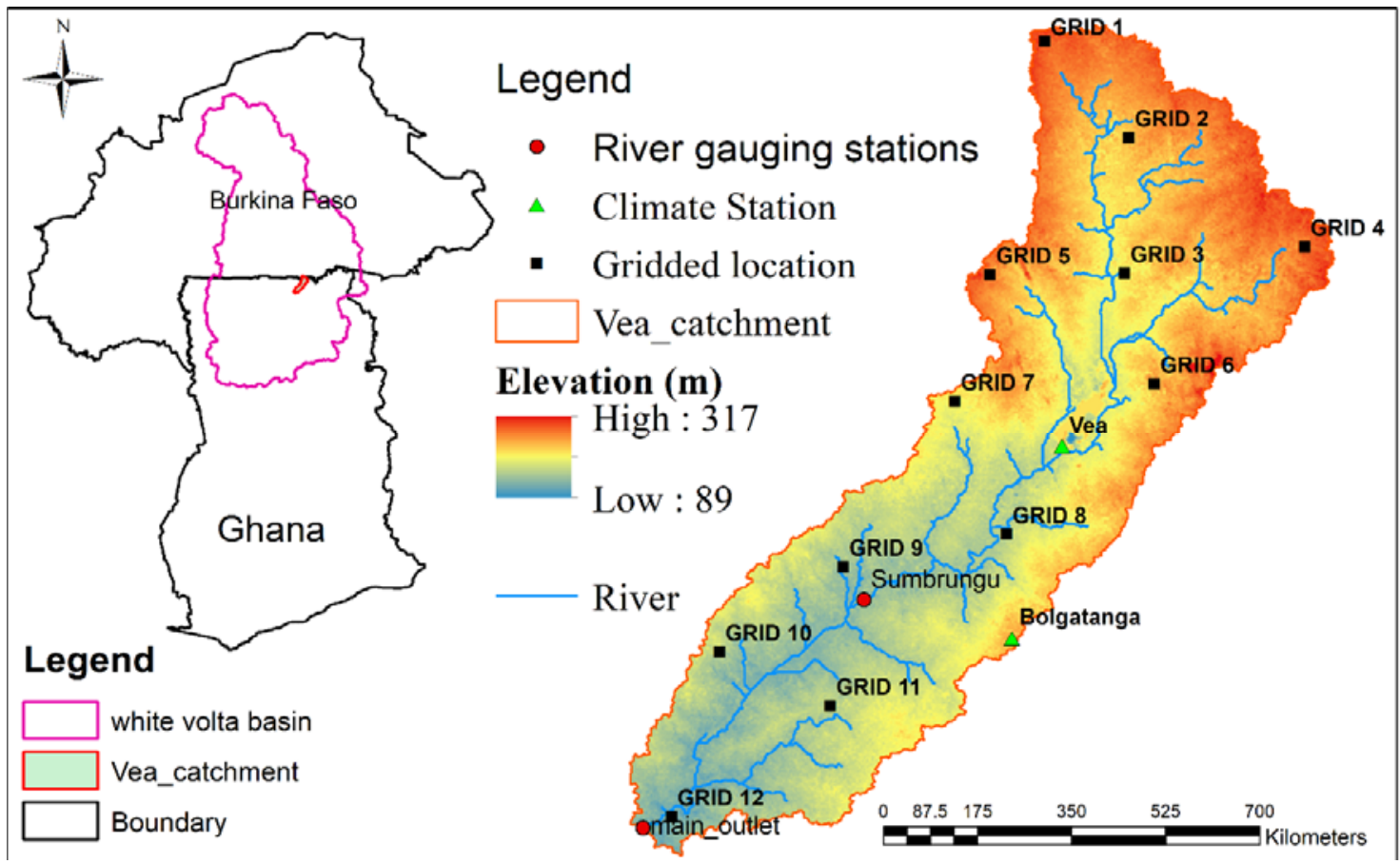

Figure 1 Location of the Vea catchment within the White Volta Basin, as well as the topography, weather and hydrological measurement stations in the Vea catchment, after Larbi et al. (2018).

\subsection{Data collection and preparation}

The SWAT model requires a digital elevation model (DEM), daily meteorological data, soil and LULC maps and management as input data. The characteristics of the datasets used for this study and their sources are listed in Table 1. Meteorological observations for the Vea catchment were taken mainly from the Bolgatanga and Vea climate stations maintained by WASCAL (Figure 1). Due to the sparse distribution of climate stations throughout the catchment, daily precipitation data from the Climate Hazards Group InfraRed Precipitation with Station (CHIRPS) data were used to complement the observed data. CHIRPS data combines $0.05^{\circ}$ resolution satellite imagery with in-situ station data to create gridded rainfall time series (Funk et al., 2015). The CHIRPS data have been demonstrated to reproduce well both the seasonal and annual rainfall pattern of the Vea catchment, with validation resulted in a very high correlation coefficient $(r=0.99)$, and a Nash-Sutcliffe efficiency of 0.9 , indicating that the CHIRPS 
precipitation data can be employed in this study (Larbi et al. 2018). The CHIRPS daily precipitation data were extracted for the various grid locations within the Vea catchment (Figure 1). These gridded locations (Figure 1, right) were selected to represent the three agro-ecological zones namely; the Savanna zone (GRID3, GRID 4, GRID 5, GRID 6, GRID 7 and GRID 8), the Guinea Savanna (GRID 9, GRID 10, GRID 11 and GRID 12) and the north Sudanian Savanna zone (GRID 1 and GRID 2) in the study area (Larbi et al. 2018). Missing records (less than 10\%) in the Vea and Bolgatanga station data were filled with the CHIRPS precipitation data and the $0.5^{\circ}$ resolution daily minimum and maximum temperature data from the NASA Langley Research Center (LaRC) POWER project (Stackhouse et al. 2018). The LULC map (Figure 2) was obtained from the maximum likelihood algorithm classification of Landsat image of the year 2016 with the details of the LULC classification found in Larbi et al. (2019). Tables 2 and 3 show the various LULC types and the associated statistics.

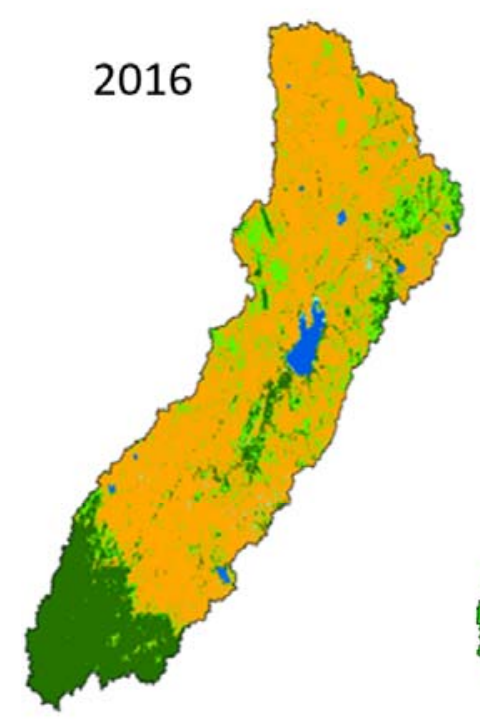

Legend

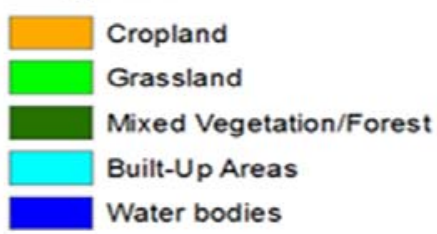

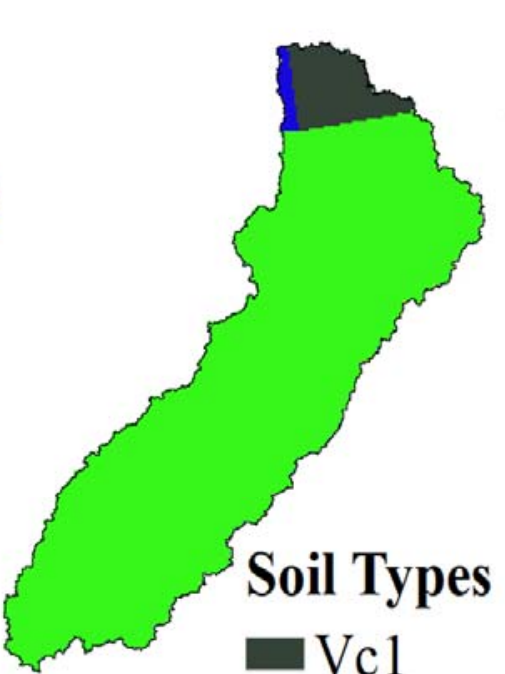

- $\mathrm{Vcl}$

Bv2

Lf1-1a

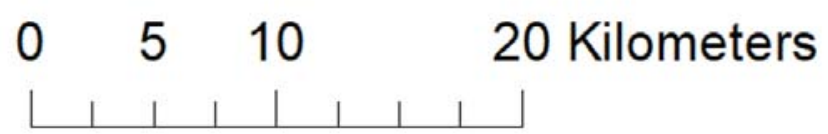

Figure 2 Land use/land cover (left), Soil (middle), and slope classes (right) maps of the Vea catchment. Lixisols (Lf1-1a), vertisols (Vc1) and cambisols (Bv2)

Table 1. Datasets used within the SWAT modelling of the Vea Catchment and their sources 


\begin{tabular}{|c|c|c|c|}
\hline $\mathrm{S} / \mathrm{N}$ & Data type & Description & Source \\
\hline 1 & DEM & $\begin{array}{l}\text { 30m digital elevation model for } \\
\text { delineation of the catchment boundary, } \\
\text { stream networks and sub-catchments. }\end{array}$ & $\begin{array}{l}\text { Shuttle Radar Topography } \\
\text { Mission (SRTM) } \\
\text { http://earthexplorer.usgs.gov/ }\end{array}$ \\
\hline 2 & Climate & $\begin{array}{l}\text { Daily rainfall }(\mathrm{mm}) \text {, maximum and } \\
\text { minimum temperature }\left({ }^{\circ} \mathrm{C}\right) \text { from } 1990- \\
2017 \text {. }\end{array}$ & $\begin{array}{l}\text { Ghana Meteorological } \\
\text { Agency, WASCAL Vea } \\
\text { catchment, CHIRPS and } \\
\text { NASA POWER }\end{array}$ \\
\hline 3 & Hydrological & $\begin{array}{l}\text { Daily discharge data from 2013-2015 } \\
\text { from Sumbrugu river gauging station } \\
\text { for calibration and validation of } \\
\text { SWAT model. }\end{array}$ & WASCAL Vea catchment \\
\hline 4 & $\begin{array}{l}\text { Soil } \\
\text { map/properties }\end{array}$ & $\begin{array}{l}\text { 10km soil map, Soil texture and } \\
\text { physical properties such as: bulk } \\
\text { density, hydrological group, available } \\
\text { water content, hydraulic conductivity } \\
\text { and organic matter content for two } \\
\text { layers }(30 \mathrm{~cm} \text { and } 100 \mathrm{~cm}) \text { for the three } \\
\text { soil types namely; lixisols (Lf1-1a), } \\
\text { vertisols (Vc1) and cambisols (Bv2) in } \\
\text { Figure } 2 \text {. }\end{array}$ & $\begin{array}{l}\text { CSIR-Soil Research Institute } \\
\text { (Ghana), Harmonized World } \\
\text { Soil Database (Dewitte et al., } \\
\text { 2013). }\end{array}$ \\
\hline 5 & $\begin{array}{l}\text { Land use/land } \\
\text { cover map }\end{array}$ & LULC map of the year 2016 & $\begin{array}{l}\text { Landsat image classification } \\
\text { (Larbi et al. 2019) }\end{array}$ \\
\hline
\end{tabular}

Table 2. Land use/ land cover classification scheme used for the Vea Catchment after Larbi et al. (2019)

\begin{tabular}{ll}
\hline LULC Categories & Description \\
\hline Water bodies & $\begin{array}{l}\text { Areas permanently covered with standing or moving water } \\
\text { such as inland waters, water logged areas, wetlands, dams, } \\
\text { dugouts, and streams. } \\
\text { Mainly mixture of grasses and shrubs with or without } \\
\text { scattered trees ( }<10 \text { trees per hectare) areas covered with } \\
\text { only grasses. }\end{array}$ \\
Built-Up areas & Areas of human settlements, roads, artificial surfaces etc. \\
Cropland & agriculture), harvested agricultural land and bare soil. \\
Forest/Mixed & Areas with dense trees usually over 5m tall, riparian \\
Vegetation & vegetation, shrub and trees. \\
\hline
\end{tabular}

Table 3. Distribution of 2016 land use/cover classes within the Vea catchment (Larbi et al. 2019) 


\begin{tabular}{lclcc}
\hline LULC type & $\begin{array}{c}\text { Redefined LULC according } \\
\text { to SWAT database }\end{array}$ & $\begin{array}{l}\text { SWAT } \\
\text { Code }\end{array}$ & Area $\left(\mathrm{km}^{2}\right)$ & $\begin{array}{c}\text { Area } \\
\text { Coverage } \\
(\%)\end{array}$ \\
\hline Cropland & Agricultural Land-Generic & AGRL & 174.50 & 56.64 \\
Grassland & Range Grass & RNGE & 82.72 & 26.85 \\
Built-Up Areas & Residential & URBN & 1.67 & 0.54 \\
Water Bodies & Range-Grasses & WATR & 4.90 & 1.59 \\
Forest/Mixed & Forest Mixed & FRST & 44.28 & 14.37 \\
Vegetation & & & & \\
\hline
\end{tabular}

\subsection{Hydrological modelling}

\subsubsection{Hydrological components of the SWAT model}

The SWAT model is an eco-hydrological model developed to simulate the quantity and quality of surface water and groundwater, and predict the environmental impact of land management practices, land use and climate change (Arnold et al. 1998, Cornelissen et al. 2013). SWAT is useful in modelling ungauged catchment and it simulates the catchment by first dividing it into sub-catchments, and then into homogenous units that consist of uniform land use, soil and slope characteristics, referred to as hydrologic response units (HRUs) (Neitsch et al. 2005). In SWAT, the quantification of the hydrological cycle components is based on the water balance equation and is expressed mathematically as:

$S W_{t}=S W_{o}+\sum_{i=1}^{t}\left(R_{\text {day }}-Q_{\text {surf }}-E T-W_{\text {seep }}-\mathrm{Lt}_{\text {flow }}-Q_{\mathrm{gw}}\right)$

where $S W_{t}$ is the final soil profile water content $(\mathrm{mm}) ; S W_{o}$ is the initial soil water content on day $i(\mathrm{~mm}) ; R_{\text {day }}, Q_{\text {surf }}, E T, W_{\text {seep }}, \mathrm{Lt}_{\text {flow }}$ and $Q_{\mathrm{gw}}$ are the daily amounts $(\mathrm{mm})$ of rainfall, surface runoff, actual evapotranspiration, percolation, lateral flow, and the groundwater flow, respectively, on day $i$. The water yield component, considered in this study consists of the contributions from surface runoff, lateral flow and groundwater flow to stream flow.

In this study, the Soil Conservation Service (SCS) curve number equation (SCSD, 1986) was used to compute the $Q_{\text {surf }} \mathrm{SWAT}$. The $\mathrm{Lt}_{\text {flow }}$ which is the lateral movement of water in the soil profile was simulated using the kinematic storage model method of Sloan and Moore (Sloan and Moore 1984), which is based on mass continuity equation. The potential evapotranspiration (PET) in this study was estimated using the Hargreaves 
method (Hargreaves and Samani, 1985), which requires only air temperature as input data. The model then computes ET once PET is determined. The groundwater recharge to the shallow aquifer is simulated by SWAT using Equation (2).

$W_{{\text {rchg }, s_{i}}_{i}}=\left(1-\exp \left\lfloor-1 / \delta_{\mathrm{gw}}\right\rfloor\right) \cdot W_{\text {seep }}+\exp \left\lfloor-1 / \delta_{\mathrm{gw}}\right\rfloor \cdot W_{\text {rchg,sa }_{i-1}}$

where $W_{\text {rchg,sa }_{i}}$ and $W_{\text {rchg,sa }}{ }_{i-1}$ are, respectively, the amount of recharge from the soil profile entering the shallow aquifer on day $i$ and on day $i-1(\mathrm{~mm})$; and $\delta_{\mathrm{gw}}$ is delay time or drainage time (days).

The Vea catchment was delineated into 52 sub-catchments with an estimated total surface area of about $306 \mathrm{~km}^{2}$ using the 30-m DEM. The 2016 LULC map and soil map were used to define the HRUs of the catchment. The multiple HRUs definition option was used to further sub-divide the Vea catchment into $331 \mathrm{HRUs}$. The model was run for the period 1990-2017; and the first three years (1990-1992) were used as model spin-up period. For a detailed description of how the SWAT model simulates the water balance components and the model set-up, readers are referred to the SWAT documentation by Neitsch et al. (2005), and the SWAT user guide of Winchell et al. (2013).

\subsubsection{Model sensitivity analysis, calibration and evaluation of prediction performance}

The SWAT model sensitivity analysis, calibration and validation were performed via the interface of SWAT-CUP using the Sequential Uncertainty Fitting version 2 (SUFI-2) procedure (Abbaspour et al. 2009). The superior capability for calibration and uncertainty analysis has been demonstrated by various studies, e.g. Shawul et al. (2013), Abbaspour et al. (2009). The sensitivity analysis was performed by testing a total of 13 parameters (Table 5) based on previous studies (Obuobie, 2008; Guug, 2017) and SWAT documentation recommendations (Neitsch et al. 2011). The SWAT model for the Vea catchment was calibrated manually as well as automatically based on the available daily observed discharge data similar to studies such as Kankam-Yeboah et al. (2013), and Dos Santos et al. (2018). The calibration was performed for the periods May 2014-November 2014 and June 2015-November 2015, and validation for the period (July-November 2013 at the Sumbrungu gauge station (Figure 1). Due to the limited length of the time series, and gaps within the observed discharge data, manual calibration was performed first based on the authors and expert knowledge of the catchment in order to ensure that the various water balance components were within reasonable and/acceptable ranges. Moreover, SWAT applications literature in the region was used to support the manual 
calibration (e.g. Obuobie 2008, Kankam-Yeboah et al. 2013, Guug, 2017). The manual calibration was performed for a limited number of parameters, including SCS runoff curve number $\left(\mathrm{CN}_{2}\right)$, soil evaporation compensation factor (ESCO), and baseflow alpha factor (ALPHA_BF), by changing one parameter at a time and re-running the model. This choice of parameters was based on previous SWAT model runs for the area (Guug 2017). Manual calibration was then followed by automatic calibration to further tune the parameters (Table 5) for the entire catchment. The performance of the SWAT model was evaluated using Nash-Sutcliffe model efficiency (NSE; Eq. (3)), coefficient of determination (R ${ }^{2}$; Eq. (4)) and percentage bias (PBIAS; Eq. (5)). The PBIAS measures the average tendency of the simulated values to be larger or smaller than the observed. The optimal value of PBIAS is 0.0 , with low-magnitude values indicating accurate model simulation. Negative values indicate overestimation, whereas positive values indicate underestimation. NSE is a commonly used statistic proposed by Nash and Sutcliffe (1970) and ranges from 1 to $-\infty$ with a value of 1 corresponding to an exact fit between modelled and measured data. The $\mathrm{R}^{2}$ gives information about the goodness of fit between the simulated data and the measured data. It ranges from 0 to 1 , with 1 being the best fit between the simulated and the observed data; typically values greater than 0.5 are considered acceptable (Santhi et al. 2001). The model performance was rated according to the performance ratings proposed by Moriasi et al. (2007), which indicated that a hydrological model can be considered satisfactory if NSE $>0.50, \mathrm{R}^{2}>0.60$, and PBIAS is within $\pm 25 \%$ for streamflow.

$$
\begin{aligned}
& \mathrm{NSE}=1-\frac{\sum_{i=1}^{n}\left(O_{i}-P_{i}\right)^{2}}{\sum_{i=1}^{n}\left(O_{i}-\bar{O}\right)^{2}} \\
& R^{2}=\left[\frac{\sum_{i=1}^{N}\left(\mathrm{O}_{i}-\bar{O}\right)\left(\mathrm{P}_{i}-\bar{P}\right)}{\left[\sum_{i=1}^{N}\left(\mathrm{O}_{i}-\bar{O}\right)^{2}\right]^{0.5}\left[\sum_{i=1}^{N}\left(P-\overline{\mathrm{P}_{l}}\right)^{2}\right]^{0.5}}\right]^{2} \\
& \text { PBIAS }=\frac{\sum_{i=1}^{n}\left(O_{i}-P_{i}\right)}{\sum_{i=1}^{n}\left(O_{i}-\bar{O}\right)} \times 100
\end{aligned}
$$

In these equations $O_{i}$ are the measured discharge data; $P_{i}$ are the simulated discharge data, whereas $\bar{O}$ and $\bar{p}_{i}$ are the mean of the measured and simulated data, respectively.

\subsection{Land cover change scenarios and water balance impact assessment}

The 2016 LULC map and the two LULC change scenarios (BAU and afforestation) (Figure 3) used in this study were produced by Larbi et al. (2019). The 2016 LULC map was based on maximum likelihood algorithm classification of the $30-\mathrm{m}$ resolution 
Landsat image with an overall accuracy of $88 \%$. This was adopted as a baseline in order to understand and obtain information on the current hydrological status at the Vea catchment. The maps for the two scenarios were produced using the Markov chain in the Land Change modeller. The Markov chain calculates how much land transition occurs from one class to another from time $t_{0}$ to $t_{1}$ in each transition based on the historical rate of LULC changes that occurred (Eastman 2006, Olmendo et al. 2015). Based on the most dominant transitions (grassland to cropland, forest/mixed vegetation to cropland, and forest/mixed vegetation to grassland) that occurred at the Vea catchment between 1990 and 2016, the transition potential maps were produced using the multi-layer perceptron (MLP) neural network algorithm at an accuracy rate of 85\% (Larbi et al. 2019). The BAU scenario map was produced based on the probability matrix generated from the transition potential maps. In the case of afforestation scenario, the probability matrix for the forest/mixed vegetation, grassland and cropland were modified based on the definition of the afforestation scenario, while the other LULC types were assumed to be maintained till the 2025. Table 4 shows the statistics for the 2016 LULC map and projections for the two LULC scenarios. Under the BAU scenario, cropland and grassland areas are projected to increase in the year 2025 by $1.5 \%$ and $6.5 \%$, respectively, while forest $/ \mathrm{mixed}$ vegetation shows a decrease of $4.5 \%$. Under the afforestation scenario, the forest $/ \mathrm{mixed}$ vegetation and grassland showed an increase of $5.4 \%$ and $14.3 \%$, respectively, while cropland decreased by $20 \%$. Detailed information on the 2016 LULC mapping, LCM validation and the two land-use scenarios are given in Larbi et al. (2019).

After calibration and validation of the SWAT model using the 2016 LULC map, the impacts of the two LULC change scenarios on the water balance components were simulated by driving the calibrated SWAT model with the 2025 BAU and afforestation scenario LULC datasets. The SWAT model was run for each scenario using the climate for the period 1993-2017, and the results under each scenario were compared to the corresponding water balance components (actual evapotranspiration, water yield and groundwater recharge) values for the 2016 LULC condition.

Table 4. Current and 2025 LULC area statistics (in $\mathrm{km}^{2}$ ) in the Vea catchment

\begin{tabular}{lccc}
\hline LULC Class & Baseline 2016 & \multicolumn{2}{c}{2025 scenarios } \\
& & BAU & Afforestation \\
\hline Cropland & $174.50(56.6 \%)$ & $177.04(57.5 \%)$ & $155.5(51.3 \%)$ \\
Grassland & $82.72(26.8 \%)$ & $88.06(28.5 \%)$ & $94.55(31.3 \%)$ \\
Built-Up Areas & $1.67(0.5 \%)$ & $1.67(0.5 \%)$ & $1.02(0.5 \%)$ \\
\hline
\end{tabular}




\begin{tabular}{lccc}
\hline Water Bodies & $4.90(1.6 \%)$ & $4.90(1.6 \%)$ & $4.90(1.6 \%)$ \\
Forest/Mixed Vegetation & $44.28(14.4 \%)$ & $36.40(11.8 \%)$ & $46.66(15.3 \%)$ \\
\hline
\end{tabular}

Note: The areas expressed as percentages areas of the total area are in brackets.

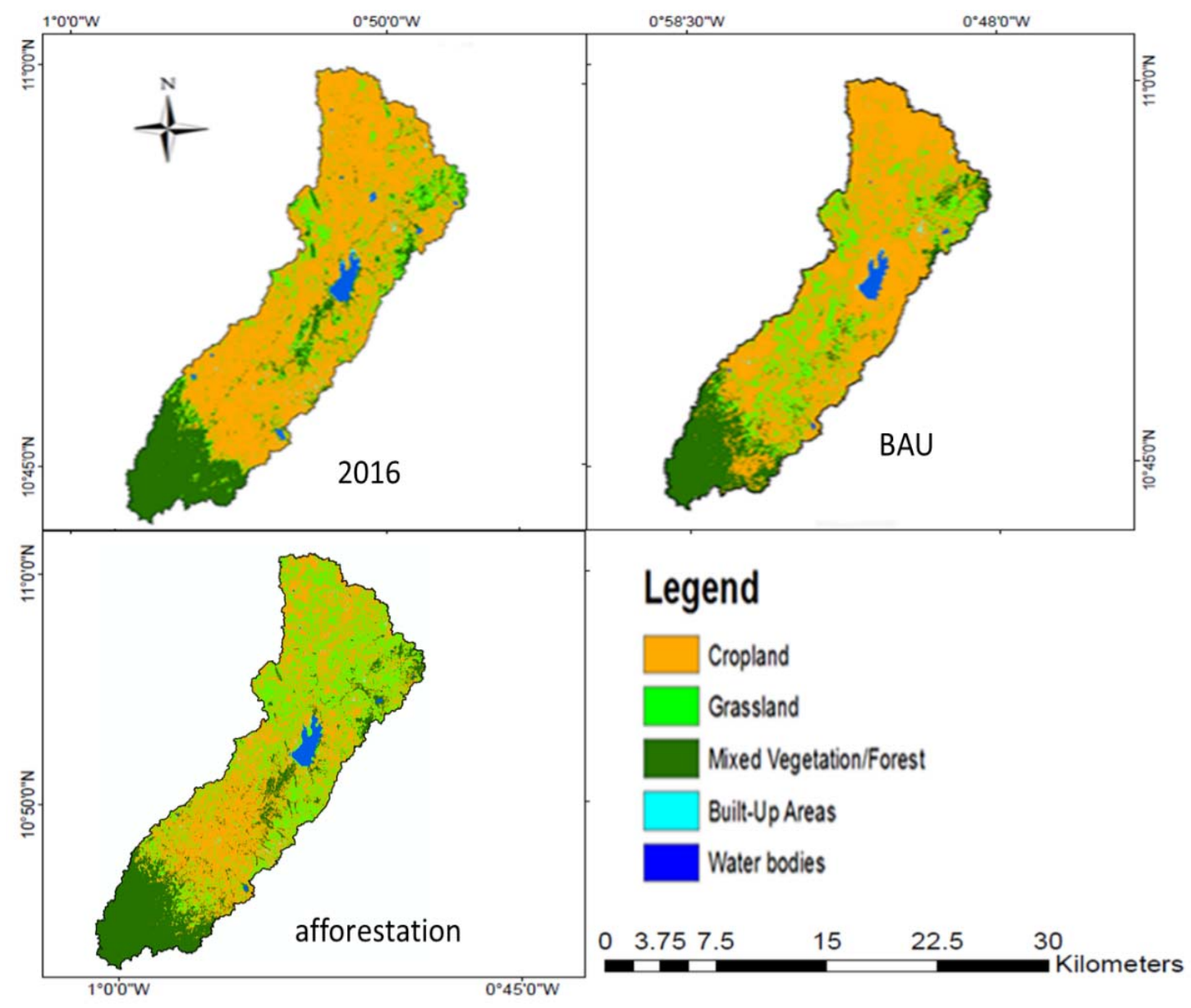

Figure 3 The baseline and 2025 LULC change scenarios maps of the Vea catchment (Larbi et al. 2019)

\section{RESULTS AND DISCUSSION}

\subsection{Sensitivity, calibration and validation of SWAT model}

A total of 13 parameters were selected and presented together with their final fitted values for the stream flow simulation with the SWAT model (Table 5). Generally, hydrological models are sensitive to parameters related to soil, weather, vegetation, land management, and channels properties (Arnold et al., 2000). The average slope steepness (HRU_SLP), SCS runoff curve number $\left(\mathrm{CN}_{2}\right)$, baseflow alpha factor (ALPHA_BF), soil evaporation 
compensation factor (ESCO) and the threshold water depth in the shallow aquifer for return flow to occur (GWQMN) emerged as the most sensitive parameters for the Vea catchment. Similar results were reported by a number of studies in the same region using the SWAT model (Obuobie, 2008; Kankam-Yeboah et al. 2013; Guug, 2017). The comparison between the observed and simulated daily stream flows for the SWAT model calibration (2014-2015) and validation (2013) periods are shown in Figure 4 and Figure 5 , respectively. The values for $\mathrm{R}^{2}$ and NSE for the calibration period were 0.75 and 0.69 , respectively, whereas for the validation periods 0.71 and 0.62 , respectively, were obtained. The PBIAS results for the calibration (10.3\%) and validation $(-18.5 \%)$ of the SWAT model are in line with the range for model satisfaction proposed by Moriasi et al. (2017), indicating that a hydrological model can be considered as satisfactory if NSE > $0.50, \mathrm{R}^{2}>0.60$, and PBIAS is within $\pm 25 \%$ for streamflow. The obtained modelling statistics are also in line with calibration results of previous SWAT modelling studies in the study region (e.g. Obuobie, 2008; Kankam-Yeboah et al. 2013, Awotwi et al. 2014). In addition, the hydrological balances produced by the SWAT model in this study are close to values found for small Sudanian catchments in the study region (Oguntunde, 2004, Martin 2005, Ibrahim et al. 2015). Therefore, the modelling statistics results provide a reasonable support for the model's ability to describe water balance components of the Vea catchment.

Table 5. Input parameters and bounds, sensitivity ranking and calibrated values by the SWAT model for the Vea catchment

\begin{tabular}{|c|c|c|c|c|}
\hline Parameters & Definition & $\begin{array}{l}\text { Lower/ } \\
\text { upper } \\
\text { bounds }\end{array}$ & $\begin{array}{c}\text { Calibrated } \\
\text { values }\end{array}$ & $\begin{array}{c}\text { Sensitivity } \\
\text { Rank }\end{array}$ \\
\hline HRU_SLP & $\begin{array}{l}\text { Average slope steepness } \\
\qquad(\mathrm{m} / \mathrm{m})\end{array}$ & $0.0-1.0$ & 0.014 & 1 \\
\hline V_CN $2 . m g t \_A G R L$ & Curve number for cropland, & $35-90$ & 72.5 & 2 \\
\hline V_CN $2 . m g t \_R N G E$ & Curve number for grassland & & 73.5 & \\
\hline V_CN $2 . m g t \_F R S T$ & $\begin{array}{c}\text { Curve number for } \\
\text { forest/mixed vegetation. }\end{array}$ & & 69.0 & \\
\hline V_ALPHA_BF.gw & Baseflow alpha factor (days) & $0.0-1.0$ & 0.02 & 3 \\
\hline V_ESCO.hru & $\begin{array}{l}\text { Soil evaporation } \\
\text { compensation factor }\end{array}$ & $0.0-1.0$ & 0.42 & 4 \\
\hline R_REVAPMN.gw & $\begin{array}{l}\text { Threshold depth of water in } \\
\text { shallow aquifer for revap to } \\
\text { occur }\end{array}$ & $0.0-1000$ & 550 & 5 \\
\hline SLSUBBSN.hru & Average slope length (m) & $10-150$ & 121.9 & 6 \\
\hline
\end{tabular}




\begin{tabular}{|c|c|c|c|c|}
\hline V_GWQMN.gW & $\begin{array}{l}\text { Threshold depth of water in } \\
\text { the shallow aquifer for return } \\
\text { flow to occur (mm ) }\end{array}$ & $0.0-5000$ & 2200 & 7 \\
\hline R_EPCO.hru & $\begin{array}{l}\text { Plant uptake compensation } \\
\text { factor }\end{array}$ & $0.0-1.0$ & 0.02 & 8 \\
\hline V_GW_REVAP.gw & $\begin{array}{l}\text { Groundwater "revap" } \\
\text { coefficient. }\end{array}$ & $0.02-0.2$ & 0.02 & 9 \\
\hline V_GW_DELAY.gw & Groundwater delay (days) & $0-500$ & 33 & 10 \\
\hline R_GW_SPYLD.gw & $\begin{array}{l}\text { Specific yield of the shallow } \\
\text { aquifer }\left(\mathrm{m}^{3} / \mathrm{m}^{3}\right)\end{array}$ & $0.0-0.4$ & 0.003 & 11 \\
\hline SURLAG.bsn & Surface runoff lag time (days) & $0.0-24$ & 2 & 12 \\
\hline R_RCHRG_DP.gw & $\begin{array}{c}\text { Deep Aquifer percolation } \\
\text { coefficient }\end{array}$ & $0.0-1.0$ & 0.25 & 13 \\
\hline BLAI_AGRL & Maximum LAI for cropland & $0.5-10$ & 3 & \\
\hline BLAI_RNGE & Maximum LAI for grassland & $0.5-10$ & 2.5 & \\
\hline BLAI_FRST & $\begin{array}{l}\text { Maximum LAI for } \\
\text { forest/mixed vegetation }\end{array}$ & $0.5-10$ & 5 & \\
\hline RDMX_AGRL & $\begin{array}{l}\text { Maximum rooting depth }(\mathrm{m}) \\
\text { for cropland }\end{array}$ & $0-4$ & 2 & \\
\hline RDMX_RNGE & $\begin{array}{l}\text { Maximum rooting depth }(\mathrm{m}) \\
\text { for grassland }\end{array}$ & $0-4$ & 2 & \\
\hline RDMX_FRST & $\begin{array}{l}\text { Maximum rooting depth }(\mathrm{m}) \\
\text { for forest/mixed vegetation }\end{array}$ & $0-4$ & 3 & \\
\hline
\end{tabular}

$\mathrm{R}$ : parameter value is multiplied by $1+$ given value; $\mathrm{V}$ : parameter value is replaced by the calibrated value

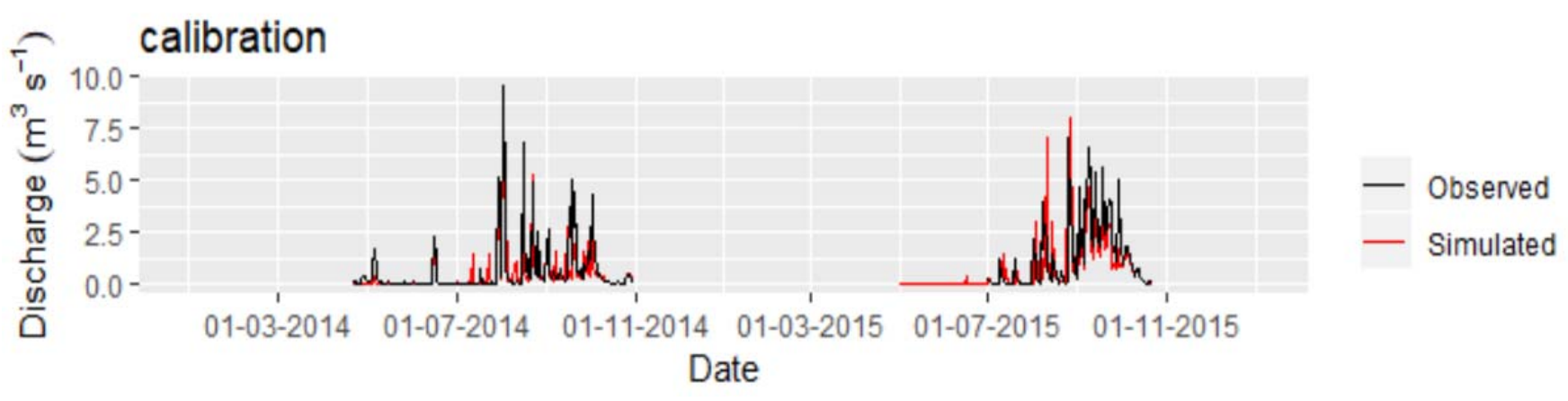

Figure 4 Simulated vs. Observed daily discharge for calibration period (2014-2015) at Sumbrungu gauge station, Vea Catchment 


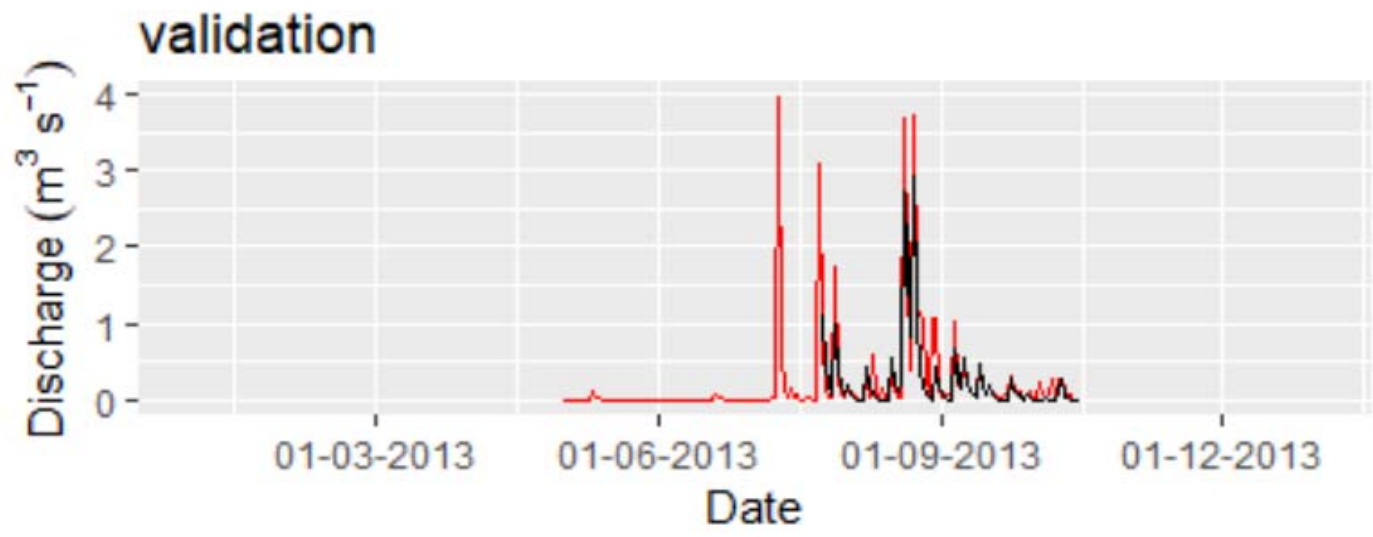

Figure 5 Simulated vs. Observed daily discharge for validation period (2013) for Sumbrungu gauge station, Vea Catchment

\subsection{Mean annual and monthly water balance components analysis}

The mean annual simulated water balance components from the baseline model run over the period 1993-2017, as a proportion of the mean annual rainfall, are shown in Figure 6. The results show that $74.3 \%$ of the mean annual rainfall $(954 \mathrm{~mm})$ is lost to ET in the catchment during the model simulation period (1993-2017). The water yield (WYLD), which consists of surface runoff, groundwater flow and lateral flow, constitutes about $13.5 \%$ of the rainfall $\left(128 \mathrm{~mm}\right.$ ), of which $Q_{-}$surf accounts for $8.6 \%$, while $Q_{\mathrm{gw}}$ and $\mathrm{Lt}_{\text {flow }}$ account for $3.4 \%$ and $1.4 \%$, respectively. The recharge to the shallow aquifer $\left(W_{\text {rchg,sa }}\right)$ is simulated to be $12.1 \%$ (115 mm). The results obtained from this study are also in line with other previous studies, such as Martin (2005), Friesen et al. (2005), Obuobie (2008) and Guug (2017). For example, a very high actual evapotranspiration (ET) within the range $73-75 \%$, runoff in the range $10-17 \%$ and shallow aquifer recharge (7-13\%) for the year 2003 were obtained by a study conducted by Martin (2005) using a simple spreadsheet-based soil water balance method for Atankwidi catchment (a $275 \mathrm{~km}^{2} \mathrm{sub}$ catchment of the White Volta in northern Ghana), which is adjacent to the Vea catchment. Similarly, Ibrahim et al. (2015) determined the water balance for the Vea catchment, from water budget modelling using the GR2M model for the period 1970-2000 and found that about $74.6 \%$ of the mean annual rainfall $(980 \mathrm{~mm})$ comprises actual evapotranspiration, with runoff and recharge being, respectively, $11.9 \%$ and $12.9 \%$ of the annual rainfall.

In terms of mean monthly distribution of the simulated water balance components (Figure 7), it was found that potential evapotranspiration (PET) exceeds rainfall in most of the months except July, August and September, which record the highest monthly 
rainfall of 173, 266 and $175 \mathrm{~mm}$, respectively. The ET increases steadily as rainfall increases during the season and decreases as the dry season approaches. During the first 6-9 weeks from the rainfall onset month (April), the model simulates rainfall being entirely partitioned by ET and the replenishment of soil moisture storage. The surface runoff therefore becomes important only after this first period of approximately 2 months; it peaks together with the water yield in August when the rainfall is highest. It is worth mentioning that the wet season is from May to October, but the water yield extends to December due to groundwater baseflow (also see Guug, 2017).

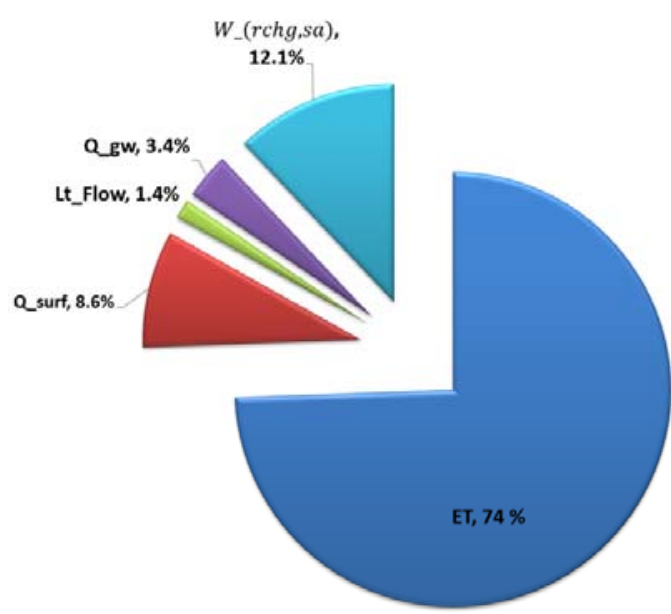

Figure 6: Mean annual water balance components as a proportion of rainfall for the Vea catchment. $Q_{\text {surf }}, E T, \mathrm{Lt}_{- \text {flow, }} Q_{-g w}$, and $W_{-(\text {rchg,sa })}$ are surface runoff, actual evapotranspiration, lateral flow, groundwater flow, shallow aquifer recharge respectively.

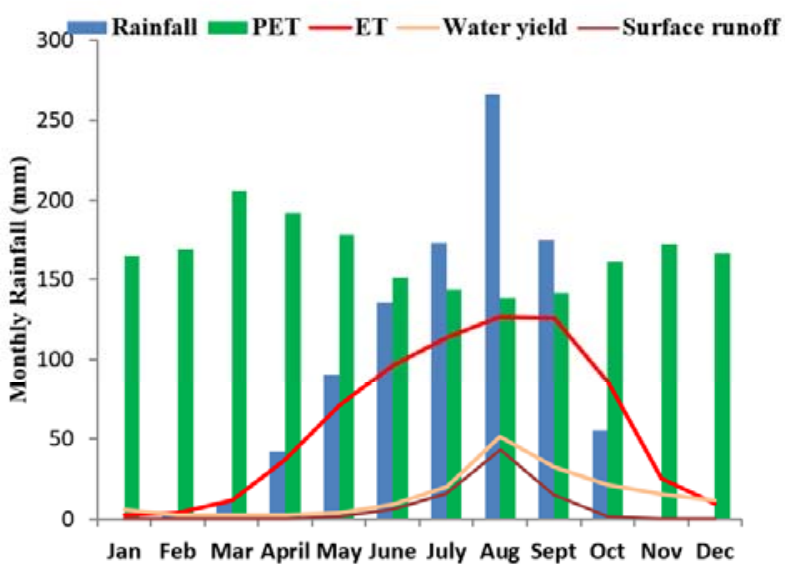

Figure 7: Mean monthly water balance components from 1993-2017 for the Vea catchment.

\subsection{Distribution of water balance components for the different LULC types}

The analysis of simulated mean annual water balance components, at the catchment scale, under different LULC types show that the lowest average annual $Q_{\text {surf }}$ is from forest/mixed vegetation, whereas the highest values occur on grassland followed by cropland (Table 6). Grassland, which covers about $26.9 \%$ of the catchment, has a mean annual $Q_{\text {surf }}$ of $100.3 \mathrm{~mm}$, followed by cropland, with $Q_{\text {surf }}$ of $88.5 \mathrm{~mm}$, whereas the lowest $Q_{\text {surf }}$ of $56.2 \mathrm{~mm}$ is found for forest/mixed vegetation. For cropland and grassland, this is equivalent to approx. $10 \%$ of the rainfall, whereas for forest/mixed vegetation it is only about $6 \%$. The actual evapotranspiration (ET) is simulated to be in the range $73-$ $74 \%$ of rainfall, i.e. the differences between the three land uses are virtually negligible. The contribution of $Q_{\mathrm{gw}}$ to streamflow is simulated to be relatively high in forest/mixed vegetation $(7.7 \%)$, follow by cropland (5.6\%), but it is low (4\%) in grassland. 
Table 6. Mean annual water balance components simulated by SWAT under different land use/cover types at catchment scale

\begin{tabular}{lcccc}
\hline LULC & $\begin{array}{c}\text { rainfall } \\
(\mathrm{mm})\end{array}$ & $\begin{array}{c}\text { Q_surf } \\
(\mathrm{mm})\end{array}$ & $Q_{g w}(\mathrm{~mm})$ & ET (mm) \\
\hline Cropland & 949.3 & $88.5(9.3 \%)$ & $50.5(5.6 \%)$ & $700.5(72.9 \%)$ \\
Forest/mixed & 972.87 & $56.2(5.8 \%)$ & $74.3(7.7 \%)$ & $720.1(74.0 \%)$ \\
vegetation & & & & \\
Grassland & 951.45 & $100.3(10.5 \%)$ & $37.9(4.0 \%)$ & $698.8(73.4 \%)$ \\
\hline
\end{tabular}

NB: Percentage rainfall contribution between brackets

\subsection{Water balance components changes under land-use scenarios}

The SWAT simulated mean monthly and annual water balance components for the period 1990-2017 under the two LULC scenarios (BAU and afforestation) were compared with those simulated for the 2016 LULC (baseline) to explore their temporal (Table 7) and spatial pattern in the Vea catchment. At the annual scale under the BAU scenario (see Section 2.4), the mean annual surface runoff, water yield and groundwater recharge increased by $18.7 \%, 9.1 \%$ and $15.3 \%$, respectively, and ET decreased by $2.7 \%$ (Table 7 ). In contrast, the opposite impact on ET occurred under the afforestation scenario, which showed a slight increase in ET by $0.6 \%$, whereas surface runoff and water yield decreased by $19.6 \%$ and $18 \%$, respectively, while groundwater recharge increased by $28.1 \%$. At the monthly scale, for the BAU scenario, the ET decreased by $4.9 \%$ in the rainy season months (May-October) and $Q_{-}$surf and WYLD increased by $18.6 \%$ and $8.7 \%$, respectively (Figure 8). Similarly, the afforestation scenario shows a $7.8 \%$ decrease in ET, $23.1 \%$ decrease in $Q_{-}$surf and $19.1 \%$ decrease in WYLD, but an increase in recharge by $21.4 \%$ in the peak period of the rainfall season (July-September). At the spatial scale under the BAU scenario, as shown in Figure 9, the ET shows a decrease in most parts of the catchment (Figure 9(b)), but water yield (Figure 9(h)) and surface runoff, especially in the central part of the catchment (Figure 9(d)-(f)), increased. Under the afforestation scenario, ET increased in the north-central part of the catchment (Figure 9(c)) and surface runoff decreased in the southern and northern parts (Figure 9(f)). The water yield decreased considerably in the entire catchment, with the highest value of $197 \mathrm{~mm}$ (Figure 9(i)), while an increase in groundwater recharge would occur at the northern part of the catchment (Figure 9(L)).

The SCS curve number $(\mathrm{CN})$ method is used by the SWAT model to compute the surface runoff for each land use. From Table 5, the $\mathrm{CN}$ for cropland, grassland and forest 
is 72.5, 73.5 and 69, respectively, with an average catchment $\mathrm{CN}$ of 71.5. Therefore, grassland had the highest surface runoff at the catchment based on $\mathrm{CN}$, followed by cropland and forest/mixed vegetation. The conversion from cropland to forest $/ \mathrm{mixed}$ vegetation would lead to a decrease in $\mathrm{CN}$ in that area and, hence, a decrease in surface runoff under the afforestation scenario. Surface runoff comprises about $63 \%$ of the water yield; hence, there would be a subsequent decrease in water yield under the afforestation scenario. On the other hand, when forest is converted to cropland and grassland, under the BAU scenario, the $\mathrm{CN}$ for the area where the conversion takes place would increase, leading to an increase in surface runoff and water yield.

The plant canopy influences infiltration, surface runoff and evapotranspiration under the different land-use types. When computing surface runoff in SWAT, the SCS $\mathrm{CN}$ method lumps the canopy interception in the term for initial abstraction. The maximum amount of water that can be held on the canopy for subsequent evaporation (interception) is a function of the leaf area index (LAI). According to Chen and Black (1992), LAI is an important modulator of ET and groundwater recharge. The maximum LAI (BLAI) values (Table 5) for forest/mixed vegetation, cropland and grassland for the Vea catchment, as simulated by the SWAT model, are 5, 3 and $2.5 \mathrm{~m}^{2} \mathrm{~m}^{-2}$, respectively, indicating higher interception in forest, followed by cropland and grassland.

Higher ET occurred in the forest/mixed vegetation (720 mm/year), followed by cropland (700.5 mm/year) and grassland (698.8 mm/year), as shown in Table 6. This is because ET is partly dependent on transpiration, which is directly proportional to the surface area of leaves (equivalent to the LAI) from which water vapour is released. According to Adane et al. (2018), the conversion from cropland to forest/mixed vegetation leads to increased rooting depth and greater LAI, which together alter the water budget considerably. Hence, under the afforestation scenario, we would expect the actual evapotranspiration to increase, while the opposite would occur under the BAU scenario.

Rooting depth determines the maximum depth from which plants can access moisture in the soil profile and it has substantial influence on groundwater recharge and actual evapotranspiration. In the SWAT model, the maximum rooting depth (RDMX) values for each land use type were $3 \mathrm{~m}$ for forest/mixed vegetation and $1 \mathrm{~m}$ for grassland and cropland (Table 5). Under both scenarios of land-use change, groundwater recharge increased: in the BAU scenario, this occurred because, although there was more surface runoff, the increased area of grassland and cropland meant lower ET. In the afforestation scenario, there was a greater infiltration rate which outweighed the increased ET. In 
addition, automatic calibration of the SWAT model indicated that water loss at the catchment was more influenced by evaporation than transpiration, as indicated by the coefficients of plant uptake and soil evaporation compensation factors which were found to be 0.02 and 0.42 , respectively (Table 5). This means that the evaporation process is sustained from deeper soil layers through capillary rise, whereas transpiration receives very little contribution from the deeper soil layers. The dominant soil type in the Vea catchment is lixisols $(90 \%)$, soils with subsurface accumulation of mainly kaolinitic clays, whereas approximately $8 \%$ of the catchment is characterized by the presence of vertisols (dominated by montmorillonite clays). Both clay types will allow for capillary rise to sustain the evaporation processes, but their water holding capacities are poor, and vertisols display pronounced cracking and swelling, which would negatively affect the transpiration process. This explains the pronounced increase in recharge under the afforestation scenario.

The decreased ET was due to the conversion of forest/mixed vegetation to cropland (see Table 7, where ET for cropland is marginally smaller than for the other two land uses). Zhang et al. (2012) indicated that a decrease in forest cover reduces ET from both canopy interception and plant transpiration. The results obtained for water yield under the BAU $(+9.1 \%)$ and afforestation $(-18 \%)$ scenarios are in accordance with other studies, such as those by De Moraes et al. (20060, Coe et al. (2009) and Dos Santos et al. (2018). For example, in the Goseng catchment, Nugroho et al. (2013) found that surface runoff and water yield (total runoff) increased due to a decrease in vegetation cover. Similarly, other studies, such as those by Bewket and Sterk (2005) and Costa et al. (2003), have confirmed that LULC change, such as the conversion of forest to agriculture and urban areas, can increase the rates of $Q_{-}$surf and groundwater recharge. According to the studies by Andréassian et al. (2004) and Brauman et al. (2007), a reduced forest coverage leads to an increase in annual flow, flood peaks and flood volume. Warburton et al. (2012) also noticed that the expansion of forest and shrub cover reduces catchment water yields and increases storage capacity, which confirms the increase in recharge obtained in this study under the afforestation scenario. Similarly, López-Moreno et al. (2013) showed that an increase in forest cover in the Upper Aragón River basin caused a decrease in annual streamflow by $16 \%$. Indeed, our results also indicate that, within the baseline model run, lower surface runoff was simulated under forest/mixed vegetation $(5.8 \%)$ compared to cropland $(9.3 \%)$ and grassland $(10.5 \%)$ which covers the greater part of the study area. 
The increased forest cover (conversion of cropland to forest/mixed vegetation) under the afforestation scenario would eventually lead to an increase in evapotranspiration due to the increase in water consumption by the trees which would increase plant transpiration (Oliveira et al. 2018). Also, the surface runoff and water yield would decrease, while recharge increases, because trees function as a means of enhancing water infiltration into the soil through the process of temporary detention of rainwater by interception, stemflow and throughfall, thus increasing the water storage (Nugroho et al. 2013). As noted by Li et al. (2018), a naturally vegetated land has relatively lower water yield coefficients due to higher rates of water infiltration. According to Mwangi et al. (2016), the ground surface roughness increases when forest/mixed vegetation increases, and this also accounts for an enhanced infiltration and a decrease in surface runoff generation. Moreover, afforestation leads to a reduction in peak flows over the hydrological year, since it increases the infiltration capacity and the effective root zone, thus increasing storage capacity (Wiekenkamp et al. 2016; Lamparter et al. 2018).

Table 7. Mean annual water balance components under 2016 and 2025 LULC change scenarios over the simulated period (1993-2017)

\begin{tabular}{lccc}
\hline Water balance components & $\begin{array}{c}\text { Baseline } \\
(2016)\end{array}$ & BAU Scenario & $\begin{array}{c}\text { afforestation } \\
\text { scenario }\end{array}$ \\
\hline Rainfall $(\mathrm{mm})$ & 954.5 & 954.5 & 954.5 \\
Actual evapotranspiration, ET (mm) & 709.5 & $689.8(-2.7 \%)$ & $714(+0.6 \%)$ \\
Surface runoff, Q_Surf $(\mathrm{mm})$ & 82.5 & $97.9(+18.7 \%)$ & $66.3(-19.6 \%)$ \\
Water yield, WYLD $(\mathrm{mm})$ & 128.4 & $140.3(+9.1 \%)$ & $105.1(-18.0 \%)$ \\
Groundwater recharge $(\mathrm{mm})$ & 115.1 & $132.8(+15.3 \%)$ & $147.4(+28.1)$ \\
\hline
\end{tabular}

NB: Values in brackets indicate percentage change in water balance component relative to the baseline for each scenario 

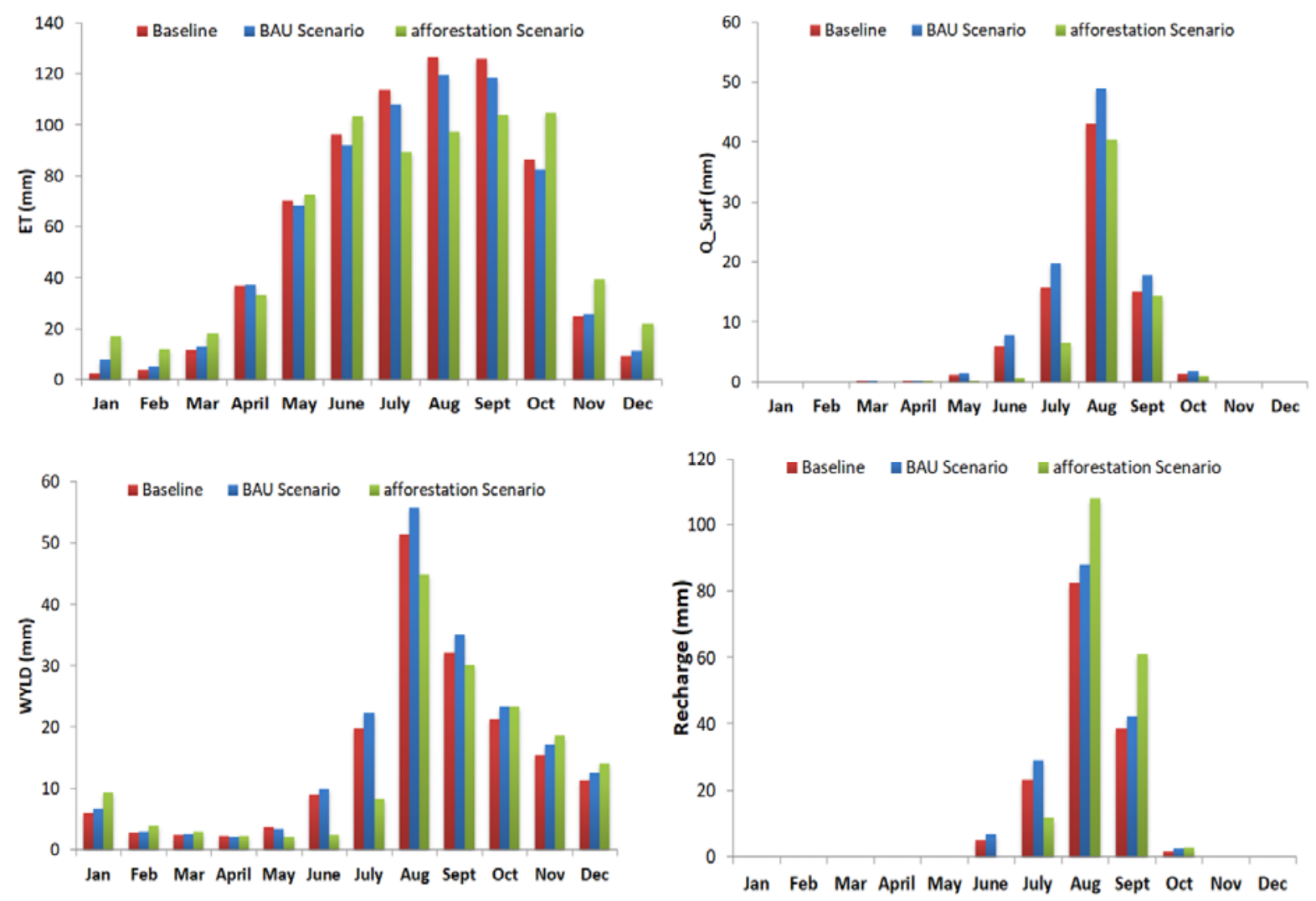

Figure 8 Mean monthly water balance components under different scenarios of land use change

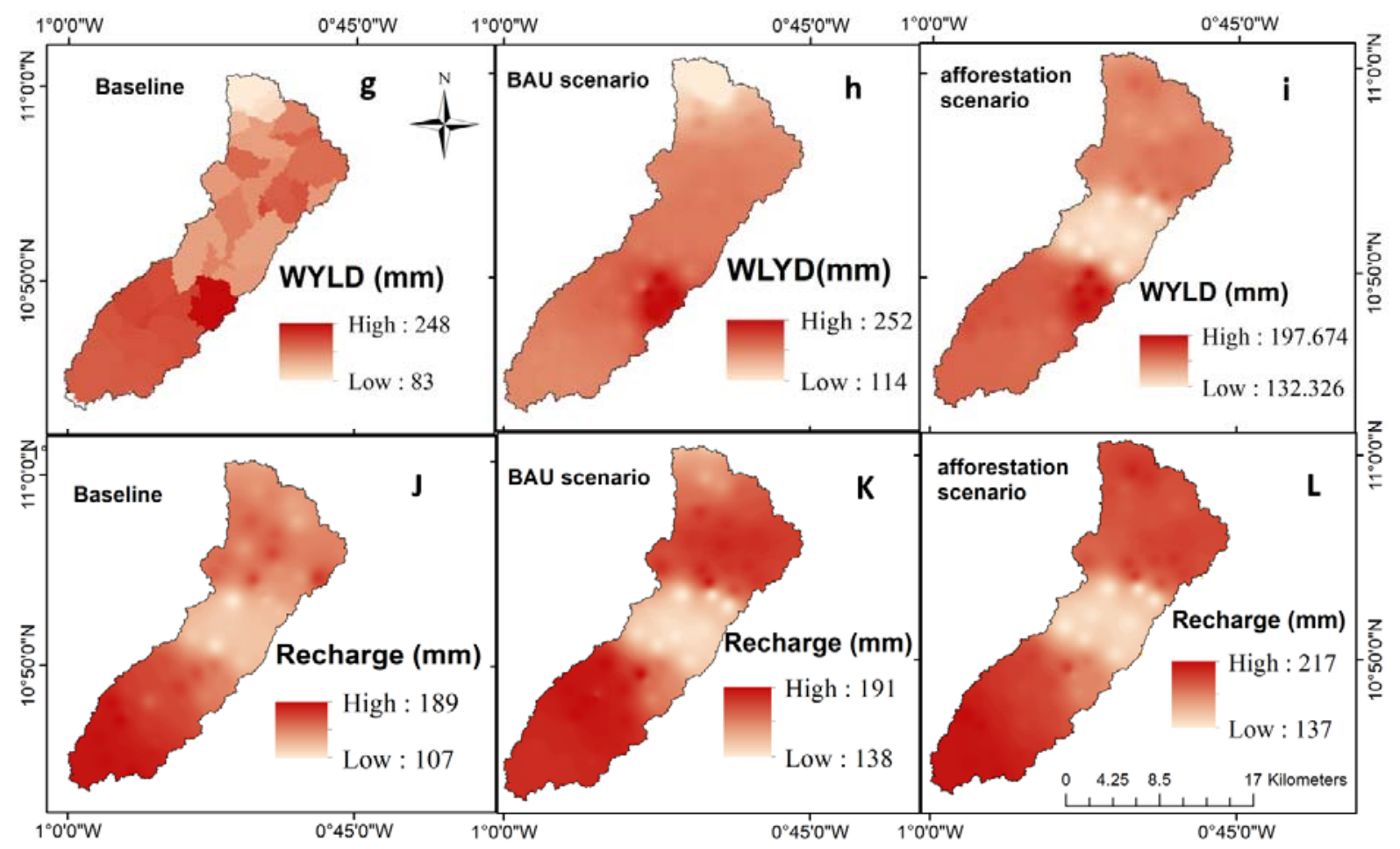

Figure 9 SWAT Simulated mean annual water balance components under BAU and afforestation scenarios of land use change relative to the baseline (2016) LULC map 


\section{CONCLUSION}

The Soil and Water Assessment Tool (SWAT) was configured for the Vea catchment to study the water balance components under business-as-usual (BAU) and afforestation scenarios of land use by forcing the SWAT model with both station and gridded precipitation and other climatic driving data. The study found that about $74 \%$ of the rainfall received at the catchment is converted into actual evapotranspiration, and the remainder is shared between the other components of the water balance. This partitioning is consistent across the three main land-use types. The magnitude of the LULC change impact on the water balance components varied, with the greatest difference between the two scenarios being for surface runoff. The changes in land use played an important role in the water balance, indicated by an increased water yield and surface runoff under the BAU scenario; these were decreased under the afforestation scenario. The conversion from cropland to forest/mixed vegetation would lead to a decrease in curve number in that area and, hence, a decrease in surface runoff and water yield under the afforestation scenario. On the other hand, the BAU scenario would lead to an increase in catchment curve number and, hence, increased surface runoff and water yield. The study also found that ET increased under the afforestation scenario but decreased under the BAU scenario due to higher leaf area index of forest/mixed vegetation which is equivalent to the surface area of leaves from which moisture can be released (either from an intercepted pool of stored water on the leaves, just after rainfall, or via transpiration when leaves are dry). In addition, it was found that water loss at the catchment was more influenced by evaporation than by transpiration (due to the physical properties of the lixisols and vertisols in this area) and, hence, the pronounced increase in recharge under the afforestation scenario. From an ecosystem service perspective, the increased water yield due to cropland and grassland expansion would contribute to the blue water available for consumption but would increase soil erosion and flood risks during storms. The increase in groundwater recharge under both scenarios of LULC change, especially under the afforestation scenario, would increase the availability of groundwater resources for different usages in the catchment. The insights acquired in this study provide a useful reference relating to the important role of land-use change in water resources planning and the need for stakeholders and policy makers to consider practical trade-offs between 
changes in water balance components and other benefits of afforestation in the smallscale Vea catchment.

\section{Acknowledgements}

This paper was extracted from Larbi's Doctoral research study undertaken at Universite D'Abomey Calavi, Benin. His sincere appreciation goes to the Federal Ministry of Education and Research (BMBF) and West African Science Centre on Climate Change and Adapted Land Use (WASCAL; www.wascal.org) for providing the scholarship and financial support for this programme. David Macdonald publishes with the permission of the Executive Director, British Geological Survey.

\section{Funding}

The contribution of A. Verhoef and D.M.J. Macdonald was supported by the BRAVE project (Building understanding of climate variability into planning of groundwater supplies from low storage aquifers in Africa), funded under the NERC/DFID/ESRC UPGro Programme [NE/M008983/1 and NE/M008827/1].

\section{Conflicts of interest}

The authors declare no conflict of interest.

\section{References}

Abbaspour, K. C. et al. 2009. Assessing the impact of climate change on water resources in Iran. Water Resources Research, 45.

Abbaspour, K.C. 2008. SWAT Calibration and Uncertainty Programs-A User Manual; Department of Systems Analysis, Integrated Assessment and Modeling (SIAM), Eawag, Swiss Federal Institute of Aquatic Science and Technology: Duebendorf, Switzerland.

Adanea, Z. A. et al. 2018. Impact of grassland conversion to forest on groundwater recharge in the Nebraska Sand Hills. Journal of hydrology: Regional studies, $15,171-183$.

Adongo, T. A. et al. 2014. Siltation of the Reservoir of Vea Irrigation Dam in the Bongo District of the Upper East Region, Ghana. International Journal of Science and Technology, 2224-3577

Andréassian, V. 2004. Waters and forests: From historical controversy to scientific debate. J. Hydrol., 291, 1-27.

Arnold, J. G. and Allen, P. M. 1993. Bernhardt, G. A comprehensive surface-groundwater flow model. Journal of hydrology, 142, 47-69. 
Arnold, J. G. et al. 1998. Large-area hydrologic modeling and assessment: Part I. Model development. J. American Water Resour. Assoc., 34(1): 73-89.

Arnold et al. 2000. Regional estimation of base flow and groundwater recharge in the Upper Mississippi River basin. Journal of Hydrology 227: 21-40. DOI:10.1016/S0022-1694(99)00139-0.

Awotwi, A. et al. 2015. Predicting hydrological response to climate change in the White Volta catchment, West Africa. Journal of Earth Science \& Climatic Change, 6, 1-7, doi:10.4172/2157-7617.1000249.

Awotwi, A., Yeboah, F., and Kumi, M. 2014. Assessing the Impact of Land Cover and Climate Changes on Water Balance Component in White Volta Basin. Water and Environment journal, doi:10.1111/wej.12100

Baatuuwie, B.N. 2015. Multi-dimensional approach for evaluating land degradation in the savanna belt of the White Volta basin. PhD dissertation, KNUST, Ghana.

Bansode, S. and Patil, K. 2016. Water Balance Assessment using Q-SWAT. International Journal of Engineering Research, Volume, 515-518.

Bewket, W., and Sterk, G. 2005. Dynamics land cover and its effect on the stream flow on the Chemoga catchment in the Blue Nile basin, Ethiopia. Hydrol. Process., $19,445-458$.

Bhaduri, B. et al. 2000. Assessing catchment-scale, long-term hydrologic impacts of land use change using a GIS-NPS model, Environ. Management, 26(6), 643-658.

Bossa, A. Y. et al. 2014. Scenario-based impacts of land use and climate change on land and water degradation from the meso to regional scale. Water, 6, 3152-3181, doi:10.3390/w6103152.

Braimoh, A.K. and Vlek, P.L.G. 2004. Land-cover change analyses in the Volta Basin of Ghana. Earth Interactions, 8, p.21.

Brauman, K.A. et al. 2007.The nature and value of ecosystem services: An overview highlighting hydrologic services. Annu. Rev. Environ. Resour., 32, 67-98.

Chen, J.M. and Black, T.A. 1992. Defining leaf area for non-flat leaves. Plant, Cell and Environment 15, pp. 421-429.

Coe et al. 2009. The influence of historical and potential future deforestation on the stream flow of the Amazon River-Land surface processes and atmospheric feedbacks. J. Hydrol.,369, 165-174.

Costa, M. H. et al. 2003. Effects of large-scale changes in land cover on the discharge of the Tocantins River, Southeastern Amazonia. Journal of Hydrology, 283: 206217.

Dewitte, O. et al. 2013. Harmonisation of the soil map of Africa at the continental scale. Geoderma 211, 138-153.

Doerr, S. H. et al. 2000. Soil water repellency: its causes, characteristics and hydro geomorphological significance, Earth-Sci. Rev.,51, 33-65.

Dos Santos et al. 2018. Hydrologic Response to Land Use Change in a Large Basin in Eastern Amazon. Water, MDPI, 10 (4), pp.429, 10.3390/w10040429.halshs01758828

De Moraes et al. 2006. Water storage and runoff processes in plinthic soils under forest and pasture in Eastern Amazonia. Hydrol. Process. 20, 2509-2526. 
Eastman, R.J. 2006. IDRISI Andes, guide to GIS and image processing. Clark University, Worcester, pp.87-131.

Forkuor, G. 2014. Agricultural Land Use Mapping in West Africa Using Multi-sensor Satellite Imagery. PhD dissertation, Julius-Maximilians-Universität Würzburg

Friesen, J. et al. 2005. Storage capacity and long-term water balance of the Volta Basin, West Africa. IAHS Publication, 296,138-145

Funk, C. et al. 2015. The climate hazards infrared precipitation with stations - a new environmental record for monitoring extremes. Scientific Data 2, 150066. doi:10.1038/sdata.2015.66 2015.

Gassman, P. W. et al. 2007. The soil and water assessment tool: historical development, applications, and future research directions. Transactions of the ASABE, 50, 1211-1250.

Ghoraba, S. M. 2015. Hydrological modeling of the Simly Dam catchment (Pakistan) using GIS and SWAT model. Alexandria Engineering Journal, 54, 583-594.

Guug, S. 2017. Modelling Water Balance and Availability with Swat Hydrological Model of the Sherigu catchment in the Upper Region of Ghana. Master's MSc Thesis, $1,1-110$.

Hargreaves, G., and Samani Z. A. 1985. Reference crop evapotranspiration from temperature, Applied engineering in agriculture 1: 96-99.

Ibrahim B. et al. 2015. Hydrological predictions for small ungauged watersheds in the Sudanian zone of the Volta basin in West Africa Journal of Hydrology: Regional Studies 4 (2015) 386-397

Jones, J. R. et al. 2015. Temporal variability of precipitation in the Upper Tennessee Valley. Journal of Hydrology: Regional Studies, 3, 125-138.

Kankam-Yeboah, K. et al. 2013. Impact of climate change on streamflow in selected river basins in Ghana. Hydrological sciences journal, 58, 773-788, doi:10.1080/02626667.2013.782101.

LAMPARTER, G. et al.2018. Modelling hydrological impacts of agricultural expansion in two macro-catchments in Southern Amazonia, Brazil. Regional Environmental Change, v. 18, n. 1, p. 91-103.

Larbi, I. et al. 2018. Spatio-Temporal Trend Analysis of Rainfall and Temperature Extremes in the Vea Catchment, Ghana. Climate, 6, 87; doi:10.3390/cli6040087

Larbi, I. et al. 2019. Predictive Land use change under business as usual and afforestation scenarios in the Vea Catchment, West Africa, International Journal of Advanced Remote Sensing and GIS, 7, Volume 8, Issue 1, pp. ISSN 2320 0243, DOI: https://doi.org/10.23953/cloud.ijarsg.416.

Li et al. 2018. Impacts of Land-Use and Land-Cover Changes on Water Yield: A Case Study in Jing-Jin-Ji, China. Sustainability, 10, 960.

Limantol, A. M. et al. 2016. Farmers' perception and adaptation practice to climate variability and change: a case study of the Vea catchment in Ghana. SpringerPlus, 5, 830, doi:10.1186/s40064-016-2433-9.

López-Moreno, J.I., et al. 2013. Impact of climate and land use change on water availability and reservoir management: Scenarios in the Upper Aragón River, 
Spanish Pyrenees. Science of the Total Environment 493, 12221231.doi.org/10.1016/j.scitotenv.2013.09.031

Mango L. M. et al. 2010. Land use and climate change impacts on the hydrology of the upper Mara River Basin, Kenya: results of a modeling study to support better resource management. Hydrol Earth Syst Sci, 15: 2245-2258.

Martin, N. 2005. Development of a water balance for the Atankwidi catchment, West Africa - A case study of groundwater recharge in a semi-arid climate. Doctoral thesis. University of Göttingen

Mohamed, E. R. 2010. Impacts and Implications of Climate Change for the Coastal Zones of Egypt. Delta., 31-50.

Moriasi, D.N. et al. 2007. Model evaluation guidelines for systematic quantification of accuracy in catchment simulations. Trans. ASABE, 50 (3), 885-900.

Mwangi, H.M. et al. 2016. Modelling the impact of agroforestry on hydrology of Mara River Basin in East Africa. Hydrological Processes, 30(18), 3139-3155. https://doi.org/10.1002/hyp.10852

Nash, J. E. and Sutcliffe, J.V. 1970. River Flow forecasting through conceptual models. Part I: A discussion of principles. J. Hydrol., 10:282-290

Neitsch, S. L. et al. 2011. Soil and water assessment tool theoretical documentation version 2009; Texas Water Resources Institute

Neitsch, S., Arnold, J., Kiniry, J., and Williams, J. 2005. Soil and Water Assessment Tool theoretical documentation - version 2005. Grassland, Soil \& Water Research Laboratory, Agricultural Research Service, and Blackland Agricultural Research Station, Temple, TX, 1-12.

Nugroho et al. 2013. Impact of land-use changes on water balance. Procedia Environmental Sciences, 17, 256-262.

Obuobie, E. 2008. Estimation of groundwater recharge in the context of future climate change in the White Volta River Basin. PhD dissertation, Rheinische Friedrich Wilhelms Universität, Bonn/ Germany.

Oguntunde, P., 2004. Evapotranspiration and omplimentarity relations in the water balance of the Volta Basin: field measurements and GIS-basedregional estimates. In: PhD Thesis, Ecology and Development Series No. 22. Cuvillier Verlag,Göttingenhttp://www.zef.de/fileadmin/webfiles/downloads/zefcecolog y development/ecol dev 22 text.pdf

Oliveira, V.A. et al. 2018. Land-use change impacts on the hydrology of the upper grande river basin, Brazil. CERNE, v. 24, n. 4, p. 334-343.

Olmedo, et al. 2015. Comparison of simulation models in terms of quantity and allocation of land change. Environ. Model. Softw, 69, pp.214-221.

Palazzoli, I. et al. 2015. Impact of prospective climate change on water resources and crop yields in the Indrawati basin, Nepal. Agricultural Systems, 133, 143-157.

Santhi, C. et al. 2001. Validation of the swat model on a large rwer basin with point and nonpoint sources. JAWRA Journal of the American Water Resources Association, 5, 1169-1188. 
Schuol, J., and Abbaspour, K. C. 2007. Using monthly weather statistics to generate daily data in a SWAT model application to West Africa. Ecological modelling, 201, 301-311.

Shawul, A. A., Alamirew, T., and Dinka, M. O. 2013. Calibration and validation of SWAT model and estimation of water balance components of Shaya mountainous catchment, Southeastern Ethiopia. Hydrology and Earth System Sciences Discussions, 13955-13978.

Sivasena, A. R and Janga, M. R. 2015. Evaluating the influence of spatial resolutions of DEM on watershed runoff and sediment yield using SWAT. J. Earth Syst. Sci.124, No. 7, pp. 1517-152

Sloan, P.G. and Moore, I.D. 1984. Modelling subsurface stormflow on steeply sloping forested watersheds. Water Resour. Res., 20, 1815-1822.

Soil Conservation Service Engineering Division (SCSD).1986. Urban Hydrology for Small Watersheds; Technical Release 55; U.S. Department of Agriculture: Washington, DC, USA.

Stackhouse, P. W. et al. 2018. POWER Release 8 (with GIS Applications) Methodology (Data Parameters, Sources, \& Validation) Documentation (Data Version 8.0.1) https://power.larc.nasa.gov/data-access-viewer/

Stonestrom, D. A., Scanlon, B. R., and Zhang, L. 2009. Introduction to special section on Impacts of Land Use Change on Water Resources. Water Resour. Res., 45, W00A00, doi:10.1029/2009WR007937.

Tang, Z. et al. 2005. Forecasting land use change and its environmental impact at a catchment scale, J. Environ. Manage., 76, 35-45.

Vilaysane, B. et al. 2015. Hydrological stream flow modelling for calibration and uncertainty analysis using SWAT model in the Xedone river basin, Lao PDR. Procedia Environmental Sciences, 28, 380-390.

Wang, N. L. et al. 2015. Variations of the glacier mass balance and lake water storage in the Tarim Basin, northwest China, over the period of 2003-2009 estimated by the ICESatGLAS data. Environ. Earth Sci., 74, 1997-2008.

Warburton M.L, Schulze R.E., and Jewitt G.P.W. 2012. Hydrological impacts of land use change in three diverse South African catchments. J Hydrol;4 14-415:118-35.

Wei, X. H., Liu, W. F., and Zhou, P. C. 2013. Quantifying the Relative Contributions of Forest Change and Climatic Variability to Hydrology in Large Catchments: A Critical Review of Research Methods. Water, (5) 728-746.

WIEKENKAMP, I. et al.2016 Spatial and temporal occurrence of preferential flow in a forested headwater catchment, Journal of Hydrology, v. 534, n. 1, p. 139-149.

Winchell, M., Srinivasan, R., Di Luzio, M., and Arnold, J. 2013. Arcswat Interface for Swat 2012; User Guide. Temple, Texas: Agricultural Experiment Station and Agricultural Research Service, US Department of Agriculture.

Yin, Z. et al. 2016. Assessing variation in water balance components in mountainous inland river basin experiencing climate change. Water, 8, 472, doi: $10.3390 / \mathrm{w} 8100472$. 
Yira, Y. et al. 2017. Modeling land use change impacts on water resources in a tropical West African catchment (Dano, Burkina Faso). J. Hydrol. 537, 187-199. doi:https://doi.org/10.1016/j.jhydrol.2016.03.052

Zhang, L., Zhao, F.F., and Brown, A.E. 2012. Predicting effects of plantations expansion on streamflow regime for catchments in Australia. Hydrology and Earth System Sciences 16: 2109-2121.

Zhang, S. et al. 2008. Recent changes of water discharge and sediment load in the Zhujiang (Pearl River) Basin, China. Glob Planet Chang, 60, 365-380. 
Table 1. Datasets used within the SWAT modelling of the Vea catchment and their sources.

\begin{tabular}{|c|c|c|c|}
\hline $\mathrm{S} / \mathrm{N}$ & Data type & Description & Source \\
\hline 1 & DEM & $\begin{array}{l}\text { 30-m DEM for delineation of the } \\
\text { catchment boundary, stream } \\
\text { networks and sub-catchments. }\end{array}$ & 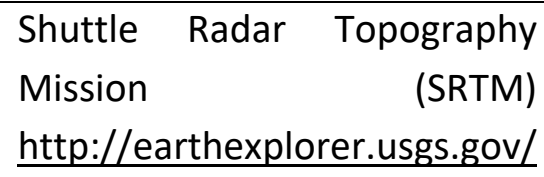 \\
\hline 2 & Climate & $\begin{array}{l}\text { Daily rainfall }(\mathrm{mm}) \text {, maximum and } \\
\text { minimum temperature }\left({ }^{\circ} \mathrm{C}\right) \text { from } \\
\text { 1990-2017. }\end{array}$ & $\begin{array}{l}\text { Ghana Meteorological Agency, } \\
\text { WASCAL Vea catchment, } \\
\text { CHIRPS and NASA POWER }\end{array}$ \\
\hline 3 & Hydrological & $\begin{array}{l}\text { Daily discharge data from 2013-2015 } \\
\text { from Sumbrugu river gauging station } \\
\text { for calibration and validation of SWAT } \\
\text { model. }\end{array}$ & WASCAL Vea catchment \\
\hline 4 & $\begin{array}{l}\text { Soil } \\
\text { map/properties }\end{array}$ & $\begin{array}{l}\text { 10-km soil map, soil texture and } \\
\text { physical properties, such as: bulk } \\
\text { density, hydrological group, available } \\
\text { water content, hydraulic conductivity } \\
\text { and organic matter content for two } \\
\text { layers ( } 30 \text { and } 100 \mathrm{~cm} \text { ) for the three } \\
\text { soil types, namely: lixisols (Lf1-1a), } \\
\text { vertisols (Vc1) and cambisols (Bv2) in } \\
\text { Fig. } 2 \text {. }\end{array}$ & $\begin{array}{l}\text { CSIR-Soil Research Institute } \\
\text { (Ghana), Harmonized World } \\
\text { Soil Database (Dewitte et al., } \\
\text { 2013). }\end{array}$ \\
\hline 5 & $\begin{array}{l}\text { Land use/land } \\
\text { cover map }\end{array}$ & LULC map of the year 2016 & $\begin{array}{l}\text { Landsat image classification } \\
\text { (Larbi et al. 2019) }\end{array}$ \\
\hline
\end{tabular}


Table 2. Land use/ land cover classification scheme used for the Vea catchment after Larbi et al. (2019).

\begin{tabular}{|c|c|}
\hline LULC Category & Description \\
\hline Water bodies & $\begin{array}{l}\text { Areas permanently covered with standing or moving water } \\
\text { such as inland waters, water-logged areas, wetlands, dams, } \\
\text { dugouts, and streams. }\end{array}$ \\
\hline Grassland & $\begin{array}{l}\text { Mainly mixture of grasses and shrubs with or without } \\
\text { scattered trees }(<10 \text { trees per hectare) areas covered with } \\
\text { only grasses. }\end{array}$ \\
\hline Built-up areas & Areas of human settlements, roads, artificial surfaces etc. \\
\hline Cropland & $\begin{array}{l}\text { Areas used for crop cultivation (irrigated and rain-fed } \\
\text { agriculture), harvested agricultural land and bare soil. }\end{array}$ \\
\hline $\begin{array}{l}\text { Forest/mixed } \\
\text { vegetation }\end{array}$ & $\begin{array}{l}\text { Areas with dense trees usually over } 5 \mathrm{~m} \text { tall, riparian } \\
\text { vegetation, shrub and trees. }\end{array}$ \\
\hline
\end{tabular}


Table 3. Distribution of 2016 land use/cover classes within the Vea catchment (Larbi et al. 2019).

\begin{tabular}{lclcc}
\hline LULC type & $\begin{array}{c}\text { Redefined LULC according } \\
\text { to SWAT database }\end{array}$ & $\begin{array}{l}\text { SWAT } \\
\text { code }\end{array}$ & Area $\left(\mathrm{km}^{2}\right)$ & $\begin{array}{c}\text { Area } \\
\text { coverage (\%) }\end{array}$ \\
\hline Cropland & Agricultural Land-Generic & AGRL & 174.50 & 56.64 \\
Grassland & Range Grass & RNGE & 82.72 & 26.85 \\
Built-Up areas & Residential & URBN & 1.67 & 0.54 \\
Water bodies & Range-Grasses & WATR & 4.90 & 1.59 \\
Forest/mixed & Forest Mixed & FRST & 44.28 & 14.37 \\
vegetation & & & & \\
\hline
\end{tabular}


Table 4. Current and 2025 LULC area statistics (in $\mathrm{km}^{2}$ ) in the Vea catchment. Values in parentheses are the percentage of the total area.

\begin{tabular}{lccc}
\hline LULC Class & Baseline 2016 & \multicolumn{2}{c}{2025 scenarios } \\
\cline { 3 - 4 } & & BAU & Afforestation \\
\hline Cropland & $174.50(56.6 \%)$ & $177.04(57.5 \%)$ & $155.5(51.3 \%)$ \\
Grassland & $82.72(26.8 \%)$ & $88.06(28.5 \%)$ & $94.55(31.3 \%)$ \\
Built-up areas & $1.67(0.5 \%)$ & $1.67(0.5 \%)$ & $1.02(0.5 \%)$ \\
Water bodies & $4.90(1.6 \%)$ & $4.90(1.6 \%)$ & $4.90(1.6 \%)$ \\
Forest/mixed vegetation & $44.28(14.4 \%)$ & $36.40(11.8 \%)$ & $46.66(15.3 \%)$ \\
\hline
\end{tabular}


Table 5. Input parameters and bounds, sensitivity ranking and calibrated values by the SWAT model for the Vea catchment.

\begin{tabular}{|c|c|c|c|c|}
\hline Parameter & Definition & $\begin{array}{l}\text { Lower/upper } \\
\text { bounds }\end{array}$ & $\begin{array}{l}\text { Calibrated } \\
\text { values }\end{array}$ & $\begin{array}{l}\text { Sensitivity } \\
\text { rank }\end{array}$ \\
\hline HRU_SLP & $\begin{array}{l}\text { Average slope steepness } \\
(\mathrm{m} / \mathrm{m})\end{array}$ & $0.0-1.0$ & 0.014 & 1 \\
\hline V_CN2.mgt_AGRL & Curve number for cropland, & $35-90$ & 72.5 & 2 \\
\hline V_CN2.mgt_RNGE & Curve number for grassland & & 73.5 & \\
\hline V_CN2.mgt_FRST & $\begin{array}{c}\text { Curve number for } \\
\text { forest/mixed vegetation }\end{array}$ & & 69.0 & \\
\hline V_ALPHA_BF.gw & Baseflow alpha factor (d) & $0.0-1.0$ & 0.02 & 3 \\
\hline V_ESCO.hru & $\begin{array}{c}\text { Soil evaporation } \\
\text { compensation factor }\end{array}$ & $0.0-1.0$ & 0.42 & 4 \\
\hline R_REVAPMN.gw & $\begin{array}{l}\text { Threshold depth of water in } \\
\text { shallow aquifer for 'revap' to } \\
\text { occur }\end{array}$ & $0.0-1000$ & 550 & 5 \\
\hline SLSUBBSN.hru & Average slope length (m) & $10-150$ & 121.9 & 6 \\
\hline V_GWQMN.gw & $\begin{array}{l}\text { Threshold depth of water in } \\
\text { the shallow aquifer for return } \\
\text { flow to occur (mm) }\end{array}$ & $0.0-5000$ & 2200 & 7 \\
\hline R_EPCO.hru & $\begin{array}{l}\text { Plant uptake compensation } \\
\text { factor }\end{array}$ & $0.0-1.0$ & 0.02 & 8 \\
\hline V_GW_REVAP.gw & $\begin{array}{c}\text { Groundwater 'revap' } \\
\text { coefficient }\end{array}$ & $0.02-0.2$ & 0.02 & 9 \\
\hline V_GW_DELAY.gw & Groundwater delay (days) & $0-500$ & 33 & 10 \\
\hline R_GW_SPYLD.gw & $\begin{array}{l}\text { Specific yield of the shallow } \\
\text { aquifer }\left(\mathrm{m}^{3} / \mathrm{m}^{3}\right)\end{array}$ & $0.0-0.4$ & 0.003 & 11 \\
\hline SURLAG.bsn & Surface runoff lag time $(\mathrm{d})$ & $0.0-24$ & 2 & 12 \\
\hline R_RCHRG_DP.gw & $\begin{array}{c}\text { Deep Aquifer percolation } \\
\text { coefficient }\end{array}$ & $0.0-1.0$ & 0.25 & 13 \\
\hline BLAI_AGRL & Maximum LAI for cropland & $0.5-10$ & 3 & \\
\hline BLAI_RNGE & Maximum LAI for grassland & $0.5-10$ & 2.5 & \\
\hline BLAI_FRST & $\begin{array}{l}\text { Maximum LAI for } \\
\text { forest/mixed vegetation }\end{array}$ & $0.5-10$ & 5 & \\
\hline RDMX_AGRL & $\begin{array}{l}\text { Maximum rooting depth }(\mathrm{m}) \\
\text { for cropland }\end{array}$ & $0-4$ & 1 & \\
\hline RDMX_RNGE & $\begin{array}{l}\text { Maximum rooting depth }(\mathrm{m}) \\
\text { for grassland }\end{array}$ & $0-4$ & 1 & \\
\hline RDMX_FRST & $\begin{array}{l}\text { Maximum rooting depth }(\mathrm{m}) \\
\text { for forest/mixed vegetation }\end{array}$ & $0-4$ & 3 & \\
\hline
\end{tabular}

$\mathrm{R}$ : parameter value is multiplied by $1+$ given value; $\mathrm{V}$ : parameter value is replaced by the calibrated value. 
Table 6. Mean annual water balance components simulated by SWAT under different land use/cover types at catchment scale. Values in parentheses are percentage rainfall contribution.

\begin{tabular}{lcccc}
\hline LULC & $\begin{array}{c}\text { Rainfall } \\
(\mathrm{mm})\end{array}$ & $Q_{\text {surf }}(\mathrm{mm})$ & $Q_{\mathrm{gw}}(\mathrm{mm})$ & ET $(\mathrm{mm})$ \\
\hline Cropland & 949.3 & $88.5(9.3 \%)$ & $50.5(5.6 \%)$ & $700.5(72.9 \%)$ \\
Forest/mixed & 972.87 & $56.2(5.8 \%)$ & $74.3(7.7 \%)$ & $720.1(74.0 \%)$ \\
vegetation & & & & \\
Grassland & 951.45 & $100.3(10.5 \%)$ & $37.9(4.0 \%)$ & $698.8(73.4 \%)$ \\
\hline
\end{tabular}


Table 7. Mean annual water balance components under 2016 and 2025 LULC change scenarios over the simulated period (1993-2017). Values in parentheses indicate the percentage change in water balance component relative to the baseline.

\begin{tabular}{lccc}
\hline Water balance component & $\begin{array}{c}\text { Baseline } \\
(2016)\end{array}$ & BAU scenario & $\begin{array}{c}\text { Afforestation } \\
\text { scenario }\end{array}$ \\
\hline Rainfall $(\mathrm{mm})$ & 954.5 & 954.5 & 954.5 \\
Actual evapotranspiration, ET $(\mathrm{mm})$ & 709.5 & $689.8(-2.7 \%)$ & $714(+0.6 \%)$ \\
Surface runoff, $Q_{\text {surf }}(\mathrm{mm})$ & 82.5 & $97.9(+18.7 \%)$ & $66.3(-19.6 \%)$ \\
Water yield, WYLD $(\mathrm{mm})$ & 128.4 & $140.3(+9.1 \%)$ & $105.1(-18.0 \%)$ \\
Groundwater recharge $(\mathrm{mm})$ & 115.1 & $132.8(+15.3 \%)$ & $147.4(+28.1)$ \\
\hline
\end{tabular}


Figure 1 Location of the Vea catchment within the White Volta Basin, as well as the topography, weather and hydrological measurement stations in the Vea catchment, after Larbi et al. (2018).

Figure 2 Maps of land use/land cover (left), soil (middle) and slope classes (right) of the Vea catchment. Vc1: vertisols; Bv2: cambisols; and Lf1-1a: lixisols.

Figure 3 Maps of the baseline and 2025 LULC change scenarios of the Vea catchment (Larbi et al. 2019).

Figure 4 Simulated vs observed daily discharge for the calibration period (2014-2015) at Sumbrungu gauge station, Vea catchment.

Figure 5 Simulated $v s$ observed daily discharge for the validation period (2013) at Sumbrungu gauge station, Vea catchment.

Figure 6 Mean annual water balance components as a proportion of rainfall for the Vea catchment. Q_surf, ET, LT_flow, Q_gw and W_rchg,sa represent surface runoff, actual evapotranspiration, lateral flow, groundwater flow, and shallow aquifer recharge, respectively.

Figure 7 Mean monthly water balance components for the period 1993-2017 for the Vea catchment.

Figure 8 Mean monthly water balance components under different scenarios of landuse change.

Figure 9 SWAT-simulated mean annual water balance components under BAU and afforestation scenarios of land-use change relative to the baseline (2016) LULC map. 